\title{
Quantitative aspects and economic implications
}

\author{
F. G. Christiansen
}

Many methods have been proposed for assessing the petroleum potential of a given region and each of these require different levels of information and knowledge (see numerous papers in Rice, 1986). Miller (1986) proposed a simplification into five basic categories of methodology:

1) Areal and volumetric yield, in combination with geological analogy.

2) Delphi or subjective consensus assessment.

3) Performance or behaviouristic extrapolation based on historical data.

4) Geochemical material balance.

5) Combinations of geological and statistical models.

These methods may be used during frontier to mature stages of exploration, either regionally, on single stratigraphic units or on specific plays or prospect types.

The present considerations of the hydrocarbon potential are based on the geochemical material balance approach. None of the other methods are adequate considering the stage of investigation and the available data.

The geochemical material balance approach is based on a stepwise evaluation of the hydrocarbon cycle (fig. 64):

1) Generative potential of source rocks.

2) Amount of hydrocarbons generated in source rocks.

3) Amount of hydrocarbons expelled from source rocks.

4) Loss during migration.

5) Amount of hydrocarbons trapped.

6) Loss during leakage, degradation.

7) Amounts of non-recoverable hydrocarbons in the reservoir.

This approach has been widely applied and is rapidly developing, thus increasing both the theoretical understanding and the sophistication of calculations (Welte \& Yukler, 1981; Bishop et al., 1983; Demaison, 1984; Kontorovich, 1984; Sluijk \& Nederlof, 1984; Ungerer et al. , 1984).

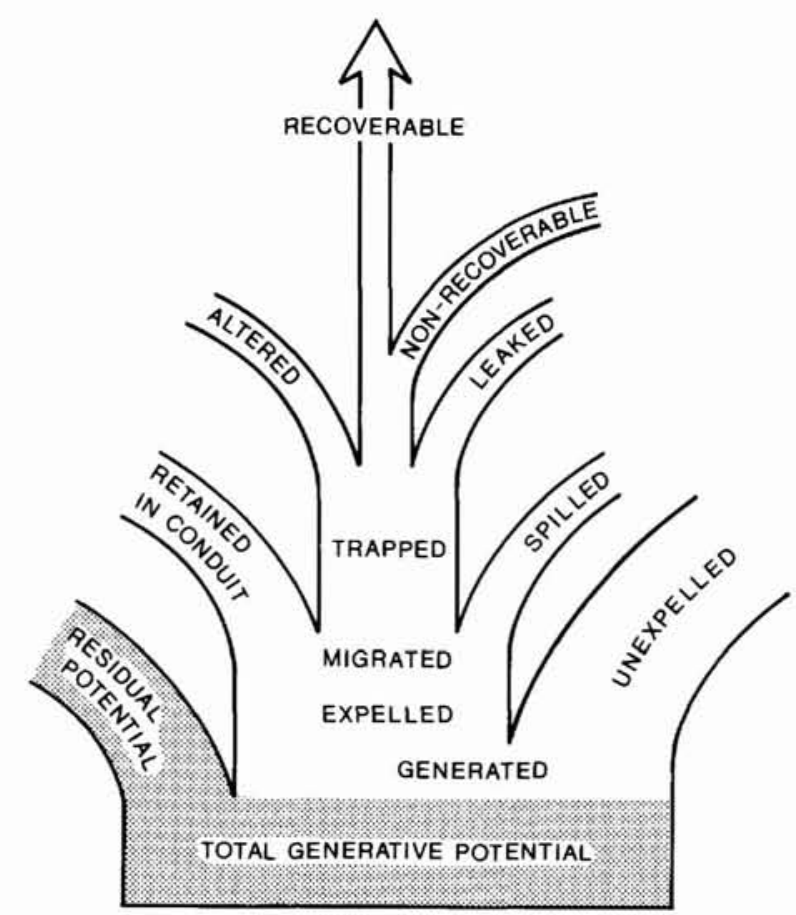

Fig. 64. Partitioning of hydrocarbons from source rock to recoverable oil in trap showing the possible losses.

Most calculations are based on dynamic basin models and provide values as a function of time and space. The models diverge in two ways in form of input and output data. Deterministic models (e.g. Welte \& Yukler, 1981) use single numbers and the most probable value is calculated. Probablistic models (e.g. Bishop et al., 1983; Sluijk \& Nederlof, 1984) employ probability distributions for both input, calculation and output and are hence much more informative. However, very large databases and computer systems are necessary for utilizing this approach.

In the following preliminary appraisal of the hydrocarbon potential in North Greenland a simple deterministic non-dynamic calculation is used. Although the 
tectonic-sedimentological development of North Greenland is fundamentally well understood (Higgins $e t$ al., in press), with a well established source rock distribution and thermal maturity pattern (Chapters 5 and 6), substantial data and work are still not available for detailed space-time-temperature modelling. Hence the main attempt in this chapter has been to estimate the order of magnitude by calculation of the ultimate potential of each source rock unit followed by discussion of generation and partitioning of hydrocarbons (see fig. 64).

\section{Generative potential of source rocks}

The hydrocarbon potential of source rocks is calculated using a simple material balance formula, either directly or summarized and integrated depending on the variation of input parameters:

Generated hydrocarbons $=$

drainage area $\times$ net thickness of source rock $\times$ density of source rock $\times$ yield $\times$ conversion constants.

The drainage area and net thickness are known from the preliminary studies of the two source rock units considered, the Henson Gletscher Formation (Christiansen et al., 1987) and the Silurian shales (Christiansen \& Nøhr-Hansen, 1988). The calculation only applies to the region between Hall Land and Freuchen Land (figs 65 and 66), where data control is good. Some of the source rocks are also distributed in Washington Land and Peary Land, but volumetric and geochemical values are not known in sufficient detail.

The yield of a given unit may be calculated as ultimate, residual or fractional (or by integration of subdivided units). The employed values are either recorded directly from the Rock Eval (S2 or S1 + S2) or from the TOC value (quantity) multiplied by either H/C (from elemental analysis) or Hydrogen Index (from Rock Eval) (quality). The conversion constant depends on the form of input data and the required output form (e.g. million barrels of hydrocarbon or million $\mathrm{m}^{3}$ of hydrocarbon).

The calculations, as in other deterministic models, are based on a set of 'most likely' values. Calculations have also been performed on minimum and maximum values of area, thickness and yield in order to ascertain the sensitivity of the estimates.

In the Silurian succession the shales of Llandovery

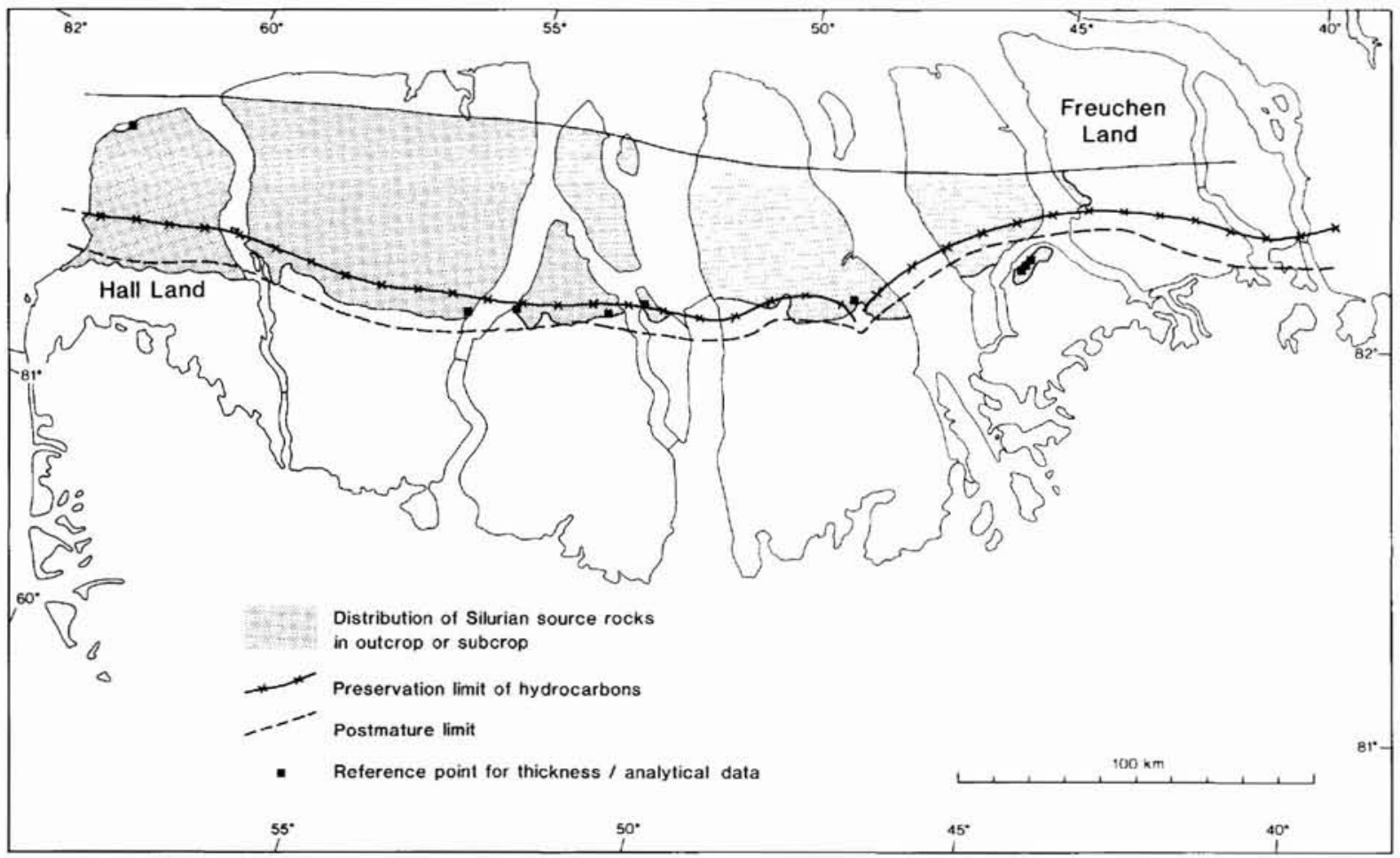

Fig. 65. Distribution of Silurian source rocks (shale groups A and B of Christiansen \& Nøhr-Hansen, 1989) in outcrop and subsurface with reference points for measurements of thickness and analytical data. The preservation limit of hydrocarbons and the postmature limit of source rocks are indicated. 


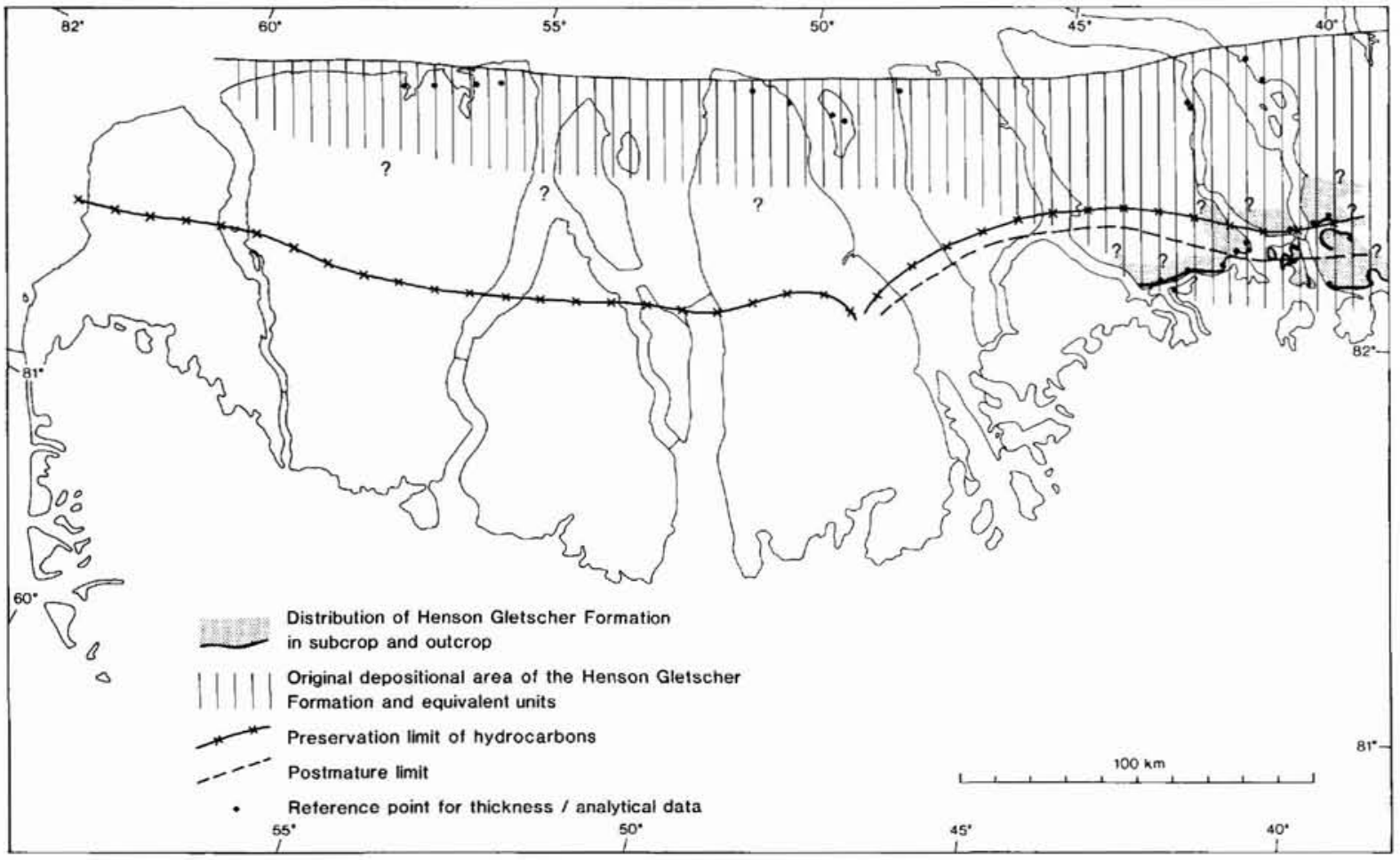

Fig. 66. Distribution of Cambrian source rocks with reference points for measurements of thickness and analytical data. The dark tone shows the outcrop and subcrop of the Henson Gletscher Formation (Christiansen et al., 1987), and the vertical hatching indicates the total original depositional area of organic-rich rocks including unit 2 of the Cambrian - Lower Silurian starved basin sequence (Higgins \& Soper, 1985; A. K. Higgins, personal communication 1987). The preservation limit of hydrocarbons and the postmature limit of source rocks are indicated.

age (group A and B of Christiansen \& Nøhr-Hansen, 1989) have a significant potential. Organic-rich shales were apparently only deposited between the reef belt and the Navarana Fjord escarpment (fig. 65) covering an area of approximately $12000 \mathrm{~km}^{2}$ with tentatively estimated minimum and maximum values of $7500 \mathrm{~km}^{2}$ and $17500 \mathrm{~km}^{2}$, respectively (Table 7).

In the Cambrian Henson Gletscher Formation estimates of the drainage area are more complex. The source rocks were traced in detail in a relatively small area until, due to the general shallow northerly dip, they disappear under younger strata (Christiansen et al., 1987). The Henson Gletscher Formation outcrops over a distance of about $100 \mathrm{~km}$ (fig. 66) and an area of 3000 $\mathrm{km}^{2}$ has been used in the calculation example (Table 7). However, the recent correlation between the Henson Gletscher Formation and unit 2 of the 'Cambrian Lower Silurian starved basin sequence' (Higgins \& Soper, 1985; Higgins et al., in press) points towards a much wider distribution of organic-rich sediments, probably covering an area of approximately $15000 \mathrm{~km}^{2}$ (fig. 66, Table 7).
The applied net thickness values are also based on information from the two preliminary studies, in the Silurian case with a subdivision into a few intervals with certain average quantity and quality parameters of the organic matter.

The yield values are based on Rock Eval measurements. Due to the good correlation between percent TOC and generative potential $(\mathrm{S} 1+\mathrm{S} 2)$ for various ranks of maturity (figs 67 and 68 ) it has been possible to estimate the initial ultimate yield of the two units and to recalculate initial TOC values.

Typical immature Silurian shales with 2 and $4 \%$ TOC are expected to have generative potentials of 8 and 18 $\mathrm{mg} \mathrm{HC} / \mathrm{g}$ rock, respectively. At increasing maturity, e.g. at peak to late generation conditions of $T_{\max }$ between $445^{\circ} \mathrm{C}$ and $450^{\circ} \mathrm{C}$, the generative potential is reduced to 3 and $7 \mathrm{mg} \mathrm{HC} / \mathrm{g}$ rock, respectively (fig. 67). The Cambrian source rocks seem to have a slightly lower generative potential; the initial yield for shales and lime mudstones with 2 and $4 \%$ TOC is 7 and $16 \mathrm{mg}$ $\mathrm{HC} / \mathrm{g}$ rock, respectively.

Based on analyses of detailed measured sections and 
Table 7. Calculation of generated hydrocarbons

\begin{tabular}{|c|c|c|c|c|c|}
\hline & $\begin{array}{l}\text { Drainage } \\
\text { area } \\
\mathrm{km}^{2}\end{array}$ & $\begin{array}{c}\text { Thickness (m) } \\
\text { with initial } \\
\text { TOC\% }\end{array}$ & $\begin{array}{c}\text { Initial yield } \\
\mathrm{mg} \mathrm{HC} / \mathrm{g} \text { rock }\end{array}$ & $\begin{array}{l}\text { Generated HC } \\
10^{3} \text { mill. } \mathrm{m}^{3} \mathrm{HC}\end{array}$ & $\begin{array}{l}\text { 'Palaco-potential' } \\
\text { with } 1 \% \text { efficiency } \\
\text { mill. barrels } \mathrm{HC}\end{array}$ \\
\hline \multicolumn{6}{|l|}{ Silurian } \\
\hline $\begin{array}{l}\text { Most } \\
\text { likely }\end{array}$ & 12000 & $\begin{array}{c}5(5 \% \text { TOC }) \\
20(3 \% \text { TOC }) \\
75(1.5 \% \text { TOC })\end{array}$ & $\begin{array}{r}26 \\
14 \\
6\end{array}$ & 32.25 & 2029 \\
\hline Maximum & 17500 & $\begin{array}{r}10(5 \% \text { TOC }) \\
25(3 \% \text { TOC }) \\
100(2 \% \text { TOC })\end{array}$ & $\begin{array}{r}26 \\
14 \\
8\end{array}$ & 77.11 & 4850 \\
\hline Minimum & 7500 & $\begin{array}{l}20(3 \% \text { TOC }) \\
60(1.5 \% \text { TOC })\end{array}$ & $\begin{array}{r}14 \\
6\end{array}$ & 9.60 & 604 \\
\hline $\begin{array}{l}\text { Cambrian } \\
\text { Maximum }\end{array}$ & 15000 & $30(3.5 \%$ TOC $)$ & 14 & 19.69 & 1239 \\
\hline Minimum & 3000 & $30(2.5 \%$ TOC $)$ & 9 & 2.53 & 159 \\
\hline
\end{tabular}

drill cores (see results in Christiansen \& Nøhr-Hansen, 1989) the TOC distribution of the Silurian shales has been simplified to a 'most likely' thickness of $5 \mathrm{~m}$ with

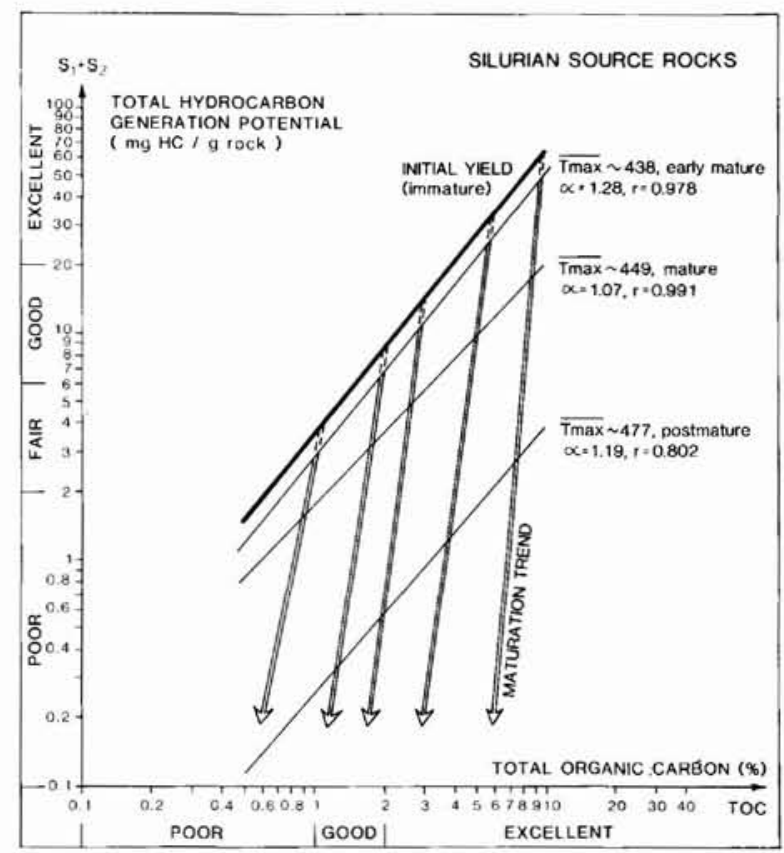

Fig. 67. Plot of \% TOC versus generation potential $(\mathrm{S} 1+\mathrm{S} 2)$ for Silurian source rocks at various ranks of maturity. The linear relation is expressed as the slope $(\alpha)$ and the regression coefficient $(r)$. The linear relation for an immature source rock is shown as a thick line, the maturation trend as double arrows.
$5 \%$ initial TOC, $20 \mathrm{~m}$ with $3 \%$ initial TOC and $75 \mathrm{~m}$ with $1.5 \%$ initial TOC.

In the Cambrian sequence an average total source

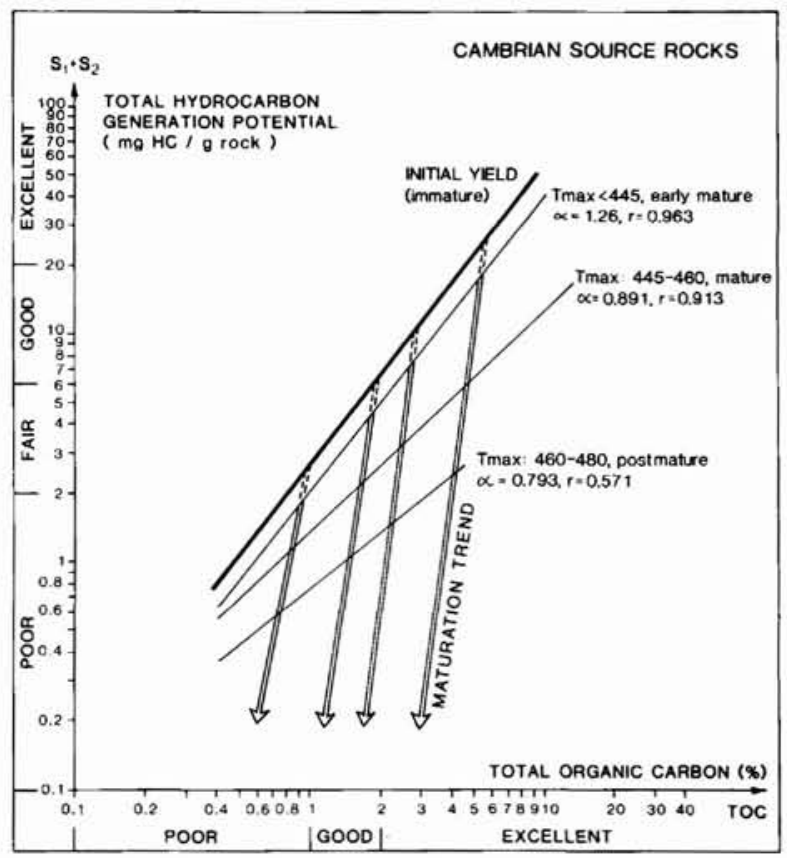

Fig. 68. Plot of \% TOC versus generation potential $(\mathrm{S} 1+\mathrm{S} 2)$ for Cambrian source rocks with various ranks of maturity. The linear relation is expressed as the slope $(\alpha)$ and the regression coefficient $(r)$. The linear relation for an immature source rock is shown as a thick line, the maturation trend as double arrows. 
rock thickness of $30 \mathrm{~m}$ has been applied in all calculations. Christiansen et al. (1987) mention a cumulative source thickness between 25 and $40 \mathrm{~m}$ (with an estimated average of $30 \mathrm{~m}$ ) in the southern part of the region. Towards the north A. K. Higgins (personal communication, 1987) reports 10 measured sections with a formation thickness between 21 and $31 \mathrm{~m}$ (average 27 $\mathrm{m})$; these values also include some sandstone intervals.

Only liquid hydrocarbons are considered in the calculations since any natural gas generated during the Ellesmerian orogeny will have leaked to the surface. The main potential of the source rocks is paraffinic crudes.

\section{Amounts of hydrocarbons generated}

Table 7 shows the amounts of hydrocarbons that would have been generated if all the studied source rocks had undergone a complete maturation history. Comparison of distribution and thermal maturity patterns (figs 65 and 66) not only suggests that most (> $90 \%$ ) of the source rocks are completely mature but also that the major part have suffered such a strong thermal alteration that no hydrocarbons remain.

The calculated values are therefore considered as a reasonable estimate of the hydrocarbons generated during thermal maturation in Late Palaeozoic time. These estimates suggest that significant amounts of hydrocarbons were generated compared to many other petroliferous basins. This is further emphasized in the right column of Table 7, where the total 'palaeo-potential' is calculated assuming an efficiency of expulsion-migration-trapping-recovery of $1 \%$. This $1 \%$ volume is close to the global percentage of generated hydrocarbons, which is considered economically recoverable (Durand, 1980). For comparison it should be noted that the production in Denmark and Norway in 1985 was 22 million barrels/year and 294 million barrels/year, respectively, and the reserves in the two countries 465 million barrels and 10900 million barrels, respectively (Yarbrough, 1986). Nassichuk (1983) proposed reserves of approximately 500 million barrels in the Lower Palaeozoic basin of the Canadian Arctic based on volumetric yield considerations.

\section{Conceptual plays}

The present knowledge of basin evolution in North Greenland (e.g. Higgins et al., in press) combined with the distribution and quality of source and reservoir rocks allow a tentative identification of a number of conceptual play models (fig. 69).

The most obvious Silurian play, also known from the Canadian Arctic (Rayer, 1981; Embry et al., in press), is shelf margin limestones and reefs as reservoirs with juxtaposed shales acting as source and seal. The combination of source rocks with interbedded porous carrier beds (mainly carbonate conglomerates and calcarenites) favours a high migration efficiency. Table 8 illustrates some highly speculative calculations of the possible order of size of single fields. The available amounts of hydrocarbons are relatively easy to calculate; the efficiencies are not known but are suggested to be considerably higher for the organic-rich units than for the leaner parts. The maximum 'palaeo-potential' of the single reefs was probably in the range from a few tens to a few hundreds of million barrels, amounts which easily could have been trapped in the larger and probably also in the smaller reefs (Table 9).

Table 8. Calculation example, single field in Silurian reef

\begin{tabular}{lcrll}
$\begin{array}{l}\text { Drainage } \\
\text { area } \mathrm{km}^{2}\end{array}$ & $\begin{array}{c}\text { Thickness }(\mathrm{m}) \\
\text { initial TOC\% }\end{array}$ & $\begin{array}{c}\text { Initial yield Efficiency } \\
\text { mg HC/g } \\
\text { rock }\end{array}$ & $\begin{array}{l}\text { 'Palaeo-potential' } \\
\text { mill. barrels HC }\end{array}$ \\
\hline \multirow{4}{*}{400} & $5(5 \%$ TOC) & 26 & 5 & \\
& $20(3 \%$ TOC) & 14 & 2 & 113 \\
& $75(1.5 \%$ TOC) & 6 & 0.5 & \\
\hline
\end{tabular}

Table 9. Calculation example, reservoir capacity in single Silurian reef

\begin{tabular}{|c|c|c|c|}
\hline & $\begin{array}{l}\text { Reef volume } \\
\mathrm{km}^{3}\end{array}$ & $\begin{array}{c}\text { Porosity } \\
\%\end{array}$ & $\begin{array}{c}\text { Capacity of } \\
\text { reservoired HC } \\
\text { mill. barrels }\end{array}$ \\
\hline $\begin{array}{l}\text { Maximum } \\
10 \mathrm{~km} \times 5 \mathrm{~km} \\
\times 0.5 \mathrm{~km}\end{array}$ & 25 & 20 & 31450 \\
\hline $\begin{array}{l}\text { Minimum } \\
1 \mathrm{~km} \times 1 \mathrm{~km} \\
\times 0.3 \mathrm{~km}\end{array}$ & 0.3 & 10 & 190 \\
\hline
\end{tabular}

The Silurian reef play is restricted by high thermal maturity and erosion level. Most of the reefs in the thermal mature zone are deeply eroded and are either exposed or shallowly buried down to only a few hundred metres of depth. The possible reefs further north, if present, occur down to $2 \mathrm{~km}$ below the surface, but are not likely to have any preserved hydrocarbons due to the high thermal maturity.

Two conceptual plays are suggested in the Cambrian sequence (fig. 69), both with their source in the Henson 


\section{CONCEPTUAL PLAY TYPES}

\section{A. SILURIAN REEFS}

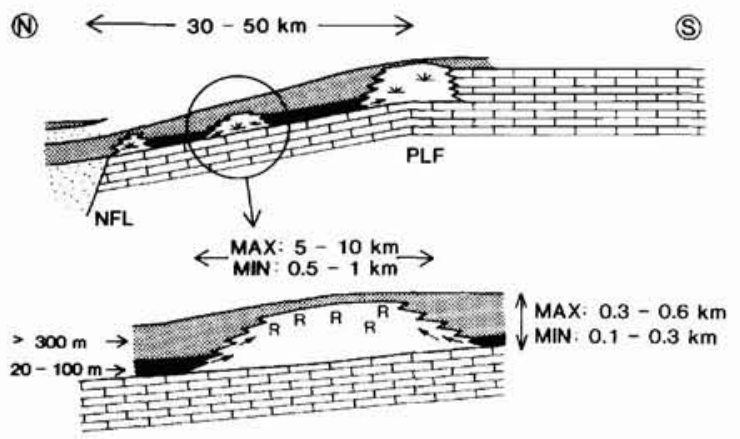

C. LONG DISTANCE MIGRATION

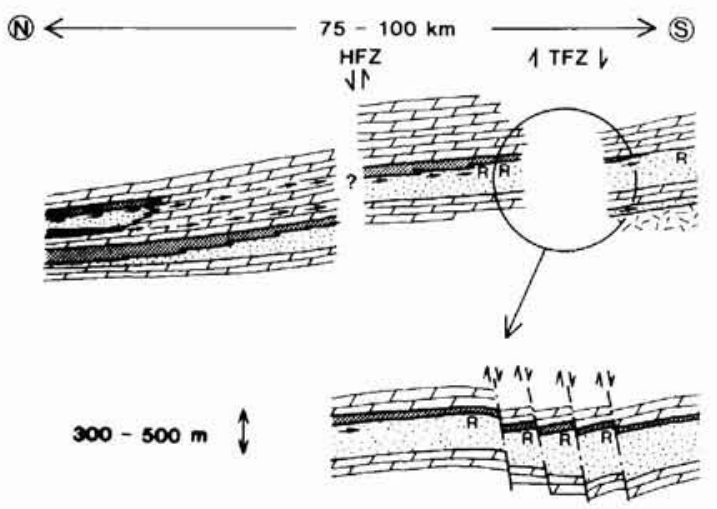

Gletscher Formation (or equivalent northern units). In both types the structural setting in the region with shallow northerly dip favours migration away from the most mature areas into thermally immature reservoirs towards the south.

The first play type includes intraformational reservoirs, especially sheet sandstones, but possibly also coarse-grained dolomites which are sealed by the enclosing source rocks. The nature of the middle siliciclastic unit is important for the migration history. Do the sheet sandstones form regionally continuous beds (blankets) which are highly efficient conduits, or do the sandstones laterally interdigitate with shale and lime mudstone? Trapping possibilities include both structural and stratigraphic types (fig. 69). Structural traps might have formed along major SW-NE trending faults or in nearby fault-induced anticlines. Stratigraphic traps might have formed where the reservoir sandstones of

\section{B. HENSON GLETSCHER INTRAFORMATIONAL}

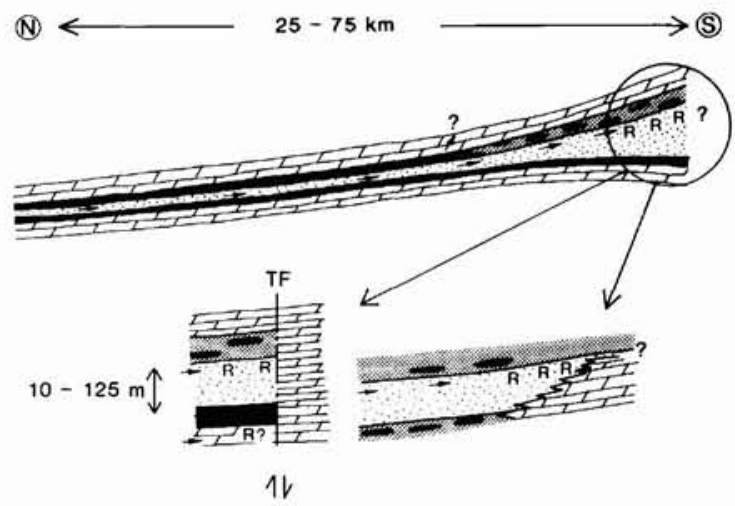

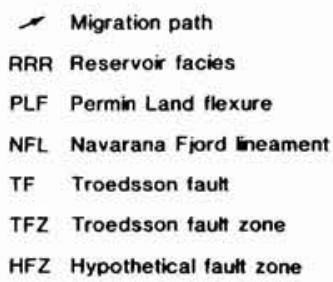

Fig. 69. Conceptual play types in central and western North Greenland. The schematic relations of potential source and reservoir rocks, migration pathways and seals are illustrated for three main prospect types, one Silurian and two Cambrian.

the Henson Gletscher Formation (or the Sæterdal Formation) interfinger with or laterally grade into impermeable intraformational bioturbated siltstones or into shallow-water dolomitized carbonates of the Ryder Gletscher Group. Due to the close association of source rocks with potential migration pathways, the efficiency of migration was probably high. This fact, combined with the large drainage areas, suggests that major accumulations could have formed at the time of maturation. However, the play is not prospective today. The areas where such stratigraphic traps were most likely to form are eroded and the areas with sufficiently buried potential traps are situated north of the inferred hydrocarbon preservation limit (fig. 66).

The second Cambrian play type includes reservoir rocks in strata older than the Henson Gletscher Formation, preferentially in the Lower Cambrian Buen Formation sandstones, but also Proterozoic sandstones or 
in possible but not yet recognized porous carbonates. This concept involves long distance migration, both laterally and along faults to older stratigraphic levels. Consequently the efficiency of migration is expected to be low $(<1 \%)$. The possibility of this play type, not only in Late Palaeozoic time but also today, is supported by the frequent staining of thermally unaltered bitumen in the potential reservoir rocks, the low thermal maturity of this part of the region, and the possible existence of subsurface structures. Both stratigraphic and structural traps are likely in this geological setting. The most simple prospective types would be that of fault-bounded reservoirs or large anticlines associated with major SW-NE faults (fig. 69).

\section{Economic implications}

The study of the hydrocarbon potential in central and western North Greenland has followed a stepwise evaluation of: (a) source rock deposition, (b) source rock quality and quantity, (c) thermal maturity history, and (d) generation products. Reservoir and trapping possibilities have not been considered in detail and only preliminary results are available. Several of these important factors provide positive indications of a petroleum potential. However, it is clear that the subsid- ence and thermal history of the source rocks are problematic. Most source rocks are thermally mature or postmature due to thermal alteration in Late Palaeozoic time. Hence the exploration prospectivity is considered limited, although clearly present.

Prospective plays involve generation of hydrocarbons more than 300 million years ago, long-distance migration and preservation in an uplifted and eroded basin. The expected limited cumulative efficiency of this playtype is partly compensated by the large amounts of generated hydrocarbons.

Among the most interesting results is the clear recognition of the regional thermal maturity pattern. Future petroleum geological activities can now be concentrated in relatively small areas outlined by the 'Nordolie' study. In addition examples of conceptual play types have been identified.

The present study also has implications for the petroleum assessment in the Canadian part of the Franklinian basin where the sedimentary succession is partly buried under Upper Palaeozoic and Mesozoic to Tertiary strata of the Sverdrup basin succession. The 'Nordolie' results may provide an important guideline for a re-evaluation of both source rocks (especially age, environment, quality and quantity, and thickness) and thermal history.

\section{Acknowledgements}

The 'Nordolie' project was supported economically by the Danish Ministry of Energy through project no. EFP-83-2251305 and so was the contribution by J. Jensenius (EFP-84-2251401). The studies by K. Hansen were supported by the Nordic Council of Ministers.

The authors are grateful to F. Rolle, O. Nykjær, J. BojesenKoefoed, O. Nygaard and K. Z. Jørgensen for their participation in the field work; to J. Boserup and G. S. Nielsen for handling, preparation and analytical work; and to $\mathrm{M}$. Larsen and V. Hermansen for the endless job of typing. B. S. Hansen made the art-work with creative enthusiasm and J. Lautrup and assistants carried out the photographic work.

The following persons have kindly commented on various drafts of one or several chapters: P. R. Dawes, I. S. Eiríksdóttir, N. Henriksen, A. K. Higgins, F. Kalsbeek, H. C. Larsen, J. S. Peel, T. C. R. Pulvertaft and M. Sønderholm. Special thanks go to F. Surlyk and W. S. Watt for their time-consuming and effective comments and editing of the final report.

Finally, thanks to N. Henriksen for his enthusiastic and energetic leadership of the expeditions to North Greenland. 


\section{References}

Aldridge, R. J., Dorning, K. J., Hill, P. J., Richardson, J. B. \& Siveter, D. J. 1979: Microfossil distribution in the Silurian of Britain and Ireland. In Harris, A. L., Holland, C. H. \& Leake, B. E. (edit.) The Caledonides of the British Isles reviewed. Spec. Publ. geol. Soc. Lond. 8, 433-438.

Allaart, J. H. 1965: The Lower Paleozoic sediments of Hall Land, North Greenland. Unpubl. intern. GGU rep., 11 pp.

Allman, M. \& Lawrence, D. F. 1972: Geological laboratory techniques, 335 pp. London: Blandford Press.

Armstrong, H. A. \& Dorning, K. J. 1984: Silurian palynomorphs from the Chester Bjerg Formation, Hall Land, western North Greenland. Rapp. Grønlands geol. Unders. 121, 97-103.

Bally, A. W. \& Snelson, S. 1980: Reals of subsidence. Bull. Can. Petrol. Geol. 28, 9-75.

Batten, D. J. 1981: Palynofacies, organic maturation and source potential for petroleum. In Brooks, J. (edit.) Organic maturation studies and fossil fuel exploration, 201-223. London: Academic Press.

Batten, D. J. 1982: Palynology of shales associated with the Kap Washington Group volcanics, central North Greenland. Rapp. Gronland geol. Unders. 108, 15-23.

Batten, D. J. 1984: Identification of amorphous sedimentary organic matter by transmitted light microscopy. In Brooks, J. (edit.) Petroleum geochemistry and exploration of Europe. Spec. Publ. geol. Soc. Lond. 12, 275-287.

Batten, D. J., Brown, P. E., Dawes, P. R., Higgins, A. K., Koch, B. E., Parson, I. \& Soper, N. J. 1981: Peralkaline volcanicity on the Eurasia basin margin. Nature 294, 150152.

Berry, W. B. N. \& Wilde, P. 1978: Progressive ventilation of the oceans - an explanation for the distribution of the Lower Palcozoic black shales. Am. J. Sci. 278, 257-275.

Bertrand, R. \& Héroux, Y. 1987: Chitinozoan, graptolite, and scolecodont reflectance as an alternative to vitrinite and pyrobitumen reflectance in Ordovician and Silurian strata, Anticosti Island, Quebec, Canada. Bull. Am. Ass. Petrol. Geol. 71, 951-957.

Bishop, R. S., Gehman, H. M. Jr., Young, A. 1983: Concepts for estimating hydrocarbon accumulation and dispersion. Bull. Am. Ass. Petrol. Geol. 67, 337-348.

Bjerreskov, M. 1986: Silurian graptolites from N Greenland. In Hughes, C. P. \& Rickards, R. B. (edit.) Palaeoecology and biostratigraphy of graptolites. Spec. Publ. geol. Soc. Lond. 20, 181-189.

Bois, C., Bouche, P. \& Pelet, R. 1982: Global geologic history and distribution of hydrocarbon reserves. Bull. Am. Ass. Petrol. 66, 1248-1270.

Bryant, I. D. \& Smith, M. P. 1985: Lowermost Ordovician sandstones in central North Greenland. Rapp. Grønlands geol. Unders. 126, 25-30.

Buchardt, B. \& Cederberg, T. 1987: EFP-83 projekt: Stabil isotop geokemi i moderbjergarter, olie og gas i Danmark, afsluttende rapport. Geologisk Centralinstitut, København, $33 \mathrm{pp}$.
Buchardt, B., Clausen, J. \& Thomsen, E. 1986: Carbon isotope composition of Lower Palaeozoic kerogen: Effects of maturation. In Leythaeuser, D. \& Rullkötter, J. (edit.) Advances in organic geochemistry 1985. Org. Geochem. 10, 127-134.

Burgess, J. D. 1974: Microscopic examination of kerogen (dispersed organic matter) in petroleum exploration. Spec. Pap. geol. Soc. Am. 153, 19-30.

Bustin, R. M., Barnes, M. A. \& Barnes, W. C. 1985a: Diagenesis 10. Quantification and modelling of organic diagenesis. Geoscience Canada 12, 4-21.

Bustin, R. M., Cameron, A. R., Grieve, D. A. \& Kalkreuth, W. D. 1985b: Coal petrology, its principles, methods, and applications. Geol. Ass. Can. Short Course Notes 3, 230 pp.

Christiansen, F. G. (edit.) 1988: Petroleum geology of North Greenland. Final report - 'Nordolie'. Unpubl. intern. GGU rep., Part I (text) 231 pp., part II (figures) 101 pp., Appendix I (previously completed papers $43+95$ pp., Appendix II (key data) $87 \mathrm{pp}$.

Christiansen, F. G. \& Nøhr-Hansen, H. 1989: The Silurian shales of central and western North Greenland: evaluation of hydrocarbon source rock potential. Rapp. Grønlands geol. Unders. 143.

Christiansen, F. G. \& Rolle, F. 1985: Project 'Nordolie': hydrocarbon source rock investigations in central North Greenland. Rapp. Grønlands geol. Unders. 125, 17-21.

Christiansen, F. G., Nøhr-Hansen, H., Rolle, F. \& Wrang, P. 1985: Preliminary analysis of the hydrocarbon source rock potential of central and western North Greenland. Rapp. Grønlands geol. Unders. 126, 117-128.

Christiansen, F. G., Nykjær, O. \& Nøhr-Hansen, H. 1986: Source rock investigations and shallow core drilling in central and western North Greenland - project 'Nordolie'. Rapp. Grønlands geol. Unders. 130, 17-23.

Christiansen, F. G., Nøhr-Hansen, H. \& Nykjær, O. 1987: The Cambrian Henson Gletscher Formation: a mature to postmature hydrocarbon source rock sequence from North Greenland. Rapp. Grønlands geol. Unders. 133, 141-157.

Christiansen, F. G., Piasecki, S. \& Stemmerik, L. in press: Petroleum, North Greenland. In Trettin, H. P. (edit.) The Innuitian Orogen and Arctic platform: Canada and Greenland. The geology of North America E. Ottawa: Geological Survey of Canada.

Christic, R. L. 1979: The Franklinian geosyncline in the Canadian Arctic and its relationship to Svalbard. Norsk Polarinstitutt, Skrifter 167, 263-314.

Christie, R. L. \& Dawes, P. R. in press: A history of exploration and geology in the Innuitian region. In Trettin, H. P. (edit.) The Innuitian Orogen and Arctic platform: Canada and Greenland. The geology of North America E. Ottawa: Geological Survey of Canada.

Christie, R. L. \& Ineson, J. R. 1979: Precambrian-Silurian geology of the G. B. Schley Fjord region, eastern Peary Land, North Greenland. Rapp. Grønlands geol. Unders. 88, 63-71. 
Christie, R. L. \& Peel, J. S. 1977: Cambrian-Silurian stratigraphy of Børglum Elv, Peary Land, eastern North Greenland. Rapp. Grønlands geol. Unders. 82, 48 pp.

Clayton, J. L. \& Swetland, P. J. 1978: Subaerial weathering of sedimentary organic matter. Geochim. cosmochim. Acta 42, 305-312.

Clementz, D. M. 1979: Effect of oil and bitumen saturation on source rock pyrolysis. Bull. Am. Ass. Petrol. Geol. 63, 22272232.

Clemmensen, L. B. 1979: Notes on the palaeogeographical setting of the Eocambrian tillite-bearing sequence of southern Peary Land, North Greenland. Rapp. Grønlands geol. Unders. 88, 15-22.

Collinson, J. D. 1979: The Proterozoic sandstones between Heilprin Land and Mylius-Erichsen Land, eastern North Greenland. Rapp. Grønlands geol. Unders. 88, 5-10.

Collinson, J. D. 1980: Stratigraphy of the Independence Fjord Group (Proterozoic) of eastern North Greenland. Rapp. Grønlands geol. Unders. 99, 7-23.

Combaz, A. 1964: Les palynofacies. Rev. Micropaleontol. Paris 7, 205-218.

Curiale, J. A. 1986: Origin of solid bitumens, with emphasis on biological marker results. In Leythaeuser, D. \& Rullkötter, J. (edit.) Advances in organic geochemistry 1985. Org. Geochem. 10, 559-580.

Davies, W. E. 1972: Landscape of northern Greenland. Spec. Rep. Cold Reg. Res. Engng. Lab. 164, 67 pp.

Davis, N. C. \& Higgins, A. K. 1987: Cambrian - Lower Silurian stratigraphy in the fold and thrust zone between northern Nyeboe Land and J. P. Koch Fjord, North Greenland. Rapp. Grønlands geol. Unders. 133, 91-98.

Dawes, P. R. 1971: The North Greenland fold belt and environs. Bull. geol. Soc. Denmark 20, 197-239.

Dawes, P. R. 1976: Precambrian to Tertiary of northern Greenland. In Escher, A. \& Watt, W. S. (edit.) Geology of Greenland, 248-303. Copenhagen: Geol. Surv. Greenland.

Dawes, P. R. 1982: The Nyeboe Land fault zone: a major dislocation on the Greenland coast along northern Nares Strait. In Dawes, P. R. \& Kerr, J. W. (edit.) Nares Strait and the drift of Greenland: a conflict in plate tectonics. Meddr Grønland Geosci. 8, 177-192.

Dawes, P. R. 1984a: Operation Grant Land 1965-1966; a geological exploration programme in Ellesmere Island and North Greenland. Rapp. Grønlands geol. Unders. 121, 5-17.

Dawes, P. R. 1984b: Programme NordGrøn (PNG) 1983-1985: regional mapping and geological studies in western and central North Greenland. Rapp. Grønlands geol. Unders. 120 , 18-24.

Dawes, P. R. \& Christie, R. L. 1982: History of exploration and geology in the Nares Strait region. In Dawes, P. R. \& Kerr, J. W. (edit.) Nares Strait and the drift of Greenland: a conflict in plate tectonics. Meddr Grønland Geosci. 8, 19-36.

Dawes, P. R. \& Christie, R. L. in press: Geomorphic regions of the Innuitian region. In Trettin, H. P. (edit.) The Innuitian Orogen and Arctic platform: Canada and Greenland. The geology of North America E. Ottawa: Geological Survey of Canada.
Dawes, P. R. \& Haller, J. 1979: Historical aspects in the geological investigation of northern Greenland. Part 1: New maps and photographs from the 2nd Thule Expedition 1916-18 and the Bicentenary Jubilee Expedition 1920-1923. Meddr Grønland 200(4), 38 pp.

Dawes, P. R. \& Kerr, J. W. (edit.) 1982: Nares Strait and the drift of Greenland: a conflict in plate tectonics. Meddr Grønland Geosci. 8, 392 pp.

Dawes, P. R. \& Peel, J. S. 1981: The northern margin of Greenland from Baffin Bay to the Greenland Sea. In Nairn, A. E. M., Churkin, M. \& Stehli, F. G. (edit.) The ocean basins and margins 5, 201-264. New York: Plenum Publ. Corp.

Dawes, P. R. \& Soper, N. J. 1970: Geological investigations in northern Peary Land. Rapp. Grønlands geol. Unders. 28, 9-15.

Dawes, P. R. \& Soper, N. J. 1973: Pre-Quaternary history of North Greenland. In Pitcher, M. G. (edit.) Arctic geology. Mem. Am. Ass. Petrol. Geol. 19, 117-134.

Dawes, P. R. \& Soper, N. J. 1979: Structural and stratigraphic framework of the North Greenland fold belt in Johannes V. Jensen Land, Peary Land. Rapp. Grønlands geol. Unders. 93, $40 \mathrm{pp}$.

Dawes, P. R. \& Soper, N. J. 1973: Pre-Quaternary history of North Greenland. In Pitcher, M. G. (edit.) Arctic geology. Mem. Am. Ass. Petrol. Geol. 19, 117-134.

W. (edit.) Nares Strait and the drift of Greenland: a conflict in plate tectonics. Meddr Grønland Geosci. 8, 89-104.

Deines, P. 1980: The isotopic composition of reduced organic matter. In Fritz, P. \& Fontez, J. Ch. (edit.) Handbook of environmental isotope geochemistry. Vol. 1, The terrestrial environment, 329-407. Amsterdam: Elsevier.

Demaison, G. 1984: The generative basin concept. In Demaison, G. \& Murris, R. J. (edit.) Petroleum geochemistry and basin evaluation. Mem. Am. Ass. Petrol. Geol. 35, 1-14.

Dorning, K. J. 1987: The organic palaeontology of Palaeozoic carbonate environments. In Hart, M. B. (edit.) Micropalaeontology of carbonate environments, 256-265. Chichester, England: Ellis Horwood Ltd.

Dow, W. G. 1977: Kerogen studies and geological interpretations. J. geochem. Expl. 7, 79-99.

Duffield, S. L. 1985: Land-derived microfossils from the Jupiter Formation (Upper Llandoverian) Anticosta Island, Québec. J. Paleont. 59, 1005-1010.

Durand, B. (edit.) 1980: Kerogen. Insoluble organic matter from sedimentary rocks, 519 pp. Paris: Editions Technip.

Ellitsgaard-Rasmussen, K. 1955: Features of the geology of the folding range of Peary Land, North Greenland. Meddr Grønland 127(7), $56 \mathrm{pp}$.

Embry, A. F., Powell, T. C. \& Mayr, U. in press: Petroleum resources, Arctic Islands. A. Petroleum. In Trettin, H. P. (edit.) The Innuitian Orogen and Arctic platform: Canada and Greenland. The geology of North America E. Ottawa: Geological Survey of Canada.

Epstein, A. G., Epstein, J. B. \& Harris, L. D. 1977: Conodont color alteration - an index to metamorphism. Prof. Pap. U.S. geol. Surv. 995, 27 pp. 
Epstein, S., Buchsbaum, R., Lowenstam, H. A. \& Urey, H. C. 1951: Carbonate-water isotopic temperature scale. Bull. geol. Soc. Am. 62, 417-425.

Escher, J. C. \& Larsen P.-H. 1987: The buried western extension of the Navarana Fjord escarpment in central and western North Greenland. Rapp. Gronlands geol. Unders. 133, 81-89.

Espitalié, J., Laporte, J. L., Madec, M., Marquis, F., Leplat, P. 1977: Methode rapide de caracterisation des roches mères de leur potentiel pétrolier et de leur degré d'évolution. Revue Inst. fr. Pétrole 32, 23-42.

Espitalié, J., Madec, M. \& Tissot, B. 1980: Role of mineral matrix in kerogen pyrolysis: influence on petroleum generation and migration. Bull. Am. Ass. Petrol. Geol. 64, 59-66.

Espatilié, J., Makadi, K. S. \& Trichet, Y. 1984: Role of the mineral matrix during kerogen pyrolysis. Org. Geochem. 6, 365-382.

Evans, R. J. \& Felbeck, Jr. G. T. 1983: High temperature simulation of petroleum formation - II. Effects of inorganic sedimentary constituents on hydrocarbon formation. Org. Geochem. 4, 145-152.

Folk, R. L. 1968: Petrology of sedimentary rocks, 170 pp. Austin, Texas: Hemphill's.

Forsberg, A. \& Bjorøy, M. 1983: A sedimentological and organic geochemical study of the Botneheia Formation, Svalbard, with special emphasis on the effects of weathering on the organic matter in shales. In Bjorøy, M. et al. (edit.) Advances in organic geochemistry 1981, 60-68. London: Wiley \& sons Ltd.

Foscolos, A. E., Powell, T. G. \& Gunther, P. R. 1976: The use of clay minerals and inorganic and organic geochemical indicators for evaluating the degrec of diagenesis and oil generating potential of shales. Geochim. cosmochim. Acta $\mathbf{4 0}$, 953-966.

Friderichsen, J. D. \& Bengaard, H.-J. 1985: The North Greenland fold belt in eastern Nansen Land. Rapp. Grønlands geol. Unders. 126, 69-78.

Friderichsen, J. D., Higgins, A. K., Hurst, J. M., Pedersen, S. A. S., Soper, N. J. \& Surlyk, F. 1982: Lithostratigraphic framework of the Upper Proterozoic and Lower Palaeozoic deep water clastic deposits of North Greenland. Rapp. Gronlands geol. Unders. 107, $20 \mathrm{pp}$.

Frisch, T. 1974: Metamorphic and plutonic rocks of northernmost Ellesmere Island, Canadian Arctic Archipelago. Bull. geol. Surv. Can. 229, 87 pp.

Galimov, E. M. 1980: ${ }^{13} \mathrm{C} /{ }^{12} \mathrm{C}$ in kerogen. In Durand, B. (edit.) Kerogen, 271-300. Paris: Editions Technip.

Gleadow, A. J. W. \& Lovering, J. F. 1978: Thermal history of granitic rocks from western Victoria: a fission track dating study. J. Geol. Soc. Aust. 25, 323-340.

Gleadow, A. J. W., Duddy, I. R. \& Lovering, J. F. 1983: Fission track analysis: a new tool for the evaluation of thermal histories and hydrocarbon potential. Austr. Petrol. Expl. Assoc. J. 23, 93-102.

Gleadow, A. J. W., Duddy, I. R., Green, P. F. \& Lovering, J. F. 1986: Confined fission track lengths in apatite: a diagnostic tool for thermal history. Contr. Mineral. Petrol. 94, $405-415$.
Glensen, P. G. \& Andrews, H. N. 1987: The evolution of early land plants. American Scientist 75, 478-489.

Glickson, M., Gibson, D. L. \& Philp, R. P. 1985: Organic matter in Australian Cambrian oil shales and Lower Palaeozoic shales. Chem. Geol. 51, 175-191.

Goodarzi, F. \& Norford, B. S. 1985: Graptolites as indicators of the temperature history of rocks. J. geol. Soc. Lond. 142, 1089-1099.

Goodarzi, F., Snowdon, L. R., Gunther, P. R. \& Jenkins, W. A. M. 1985: Preliminary organic petrography of Palaeozoic rocks from the Grand Banks, Newfoundland. Marine Petrol. Geol. 2, 254-259.

Grahn, Y. \& Nøhr-Hansen, H. 1989: Chitinozoans from Ordovician and Silurian shelf and slope sequences from North Greenland. Rapp. Grønlands geol. Unders. 144.

Grantham, P. J. 1986: The occurrence of unusual $C_{27}$ and $C_{29}$ sterane predominance in two types of Oman crude oil. Org. Geochem. 9, 1-10.

Grønlands Fiskeri- og Miljøundersøgelser 1986: Biologiske miljøundersøgelser i Nordgrønland 1984-85. Unpubl. rep., 113 pp.

Gutjahr, C. C. M. 1983: Introduction to incident-light microscopy of oil and gas source rocks. Geol. Mijnbouw 62, 417425 .

Håkansson, E. \& Stemmerik, L. 1984: Wandel Sea Basin-The North Greenland equivalent to Svalbard and the Barents Shelf. In Spencer, A. M. et al. (edit.) Petroleum geology of North European margin, 97-107. Norwegian Petroleum Society.

Hansen, B. T., Kalsbeek, F. \& Holm, P. M. 1987: Archaean age and Proterozoic metamorphic overprinting of the crystalline basement at Victoria Fjord, North Greenland. Rapp. Grønlands geol. Unders. 133, 159-168.

Hansen, K. 1985: Fission track age determinations of vertical movements in the crust caused by continental rifting: a fission track age study of the Scoresby Sund area; method and results. Unpublished lic.scient. thesis, Univ. Copenhagen, 119 pp.

Hatch, J. R., Jacobsen, S. R., Witzke, B. J., Risatti, J. B., Anders, D. E., Watney, W. L., Newell, K. D. \& Vuletich, A. K. 1987: Possible late Middle Ordovician organic carbon isotope excursion: evidence from Ordovician oils and hydrocarbon source rocks, Mid-Continent and East-Central United States. Bull. Am. Ass. Petrol. Geol. 71, 1342-1354.

Henderson, G. 1976: Petroleum geology. In Escher, A. \& Watt, W. S. (edit.) Geology of Greenland, 489-505. Copenhagen: Geol. Surv. Greenland.

Henriksen, N. 1985a: Systematic 1:500 000 mapping and regional geological studies in central and western North Greenland. Rapp. Grønlands geol. Unders. 125, 9-17.

Henriksen, N. 1985b: Systematic geological mapping in 1984 in central and western North Greenland. Rapp. Grønlands geol. Unders. 126, 5-10.

Henriksen, N. 1986: Completion of field work for the 1:500 000 mapping and regional geological studies in central and western North Greenland. Rapp. Gronlands geol. Unders. 130, 9-17.

Henriksen, N. 1987: Systematic geological mapping in 1985 in 
central and western North Greenland. Rapp. Grønlands geol. Unders. 133, 5-12.

Henriksen, N. \& Jepsen, H. F. 1985: Precambrian crystalline basement at the head of Victoria Fjord, North Greenland. Rapp. Grønlands geol. Unders. 126, 11-16.

Henriksen, N. \& Peel, J. S. 1976: Cambrian - Early Ordovician stratigraphy in southwestern Washington Land, western North Greenland. Rapp. Grønlands geol. Unders. 80, 17-23.

Heroux, Y. Chagnon, A. \& Bertrand, R. 1979: Compilation and correlation of major thermal maturation indicators. Bull. Am. Ass. Petrol. Geol. 63, 2128-2144.

Higgins, A. K. 1986: Geology of central and eastern North Greenland. Rapp. Grønlands geol. Unders. 128, 37-54.

Higgins, A. K. \& Soper, D. J. 1985: Cambrian - Lower Silurian slope and basin stratigraphy between northern Nyeboe Land and western Amundsen Land, North Greenland. Rapp. Grønlands geol. Unders. 126, 79-86.

Higgins, A. K., Mayr, U. \& Soper, N. J. 1982: Fold belts and metamorphic zones of northern Ellesmere Island and North Greenland. Rapp. Grønlands geol. Unders. 130, 9-17.

Higgins, A. K., Soper, N. J. \& Friderichsen, J. D. 1985: North Greenland fold belt in eastern North Greenland. In Gee, D. G. \& Sturt, B. A. (edit.) The Caledonide Orogen - Scandinavia and related areas, 1017-1029. London: John Wiley \& Sons Ltd.

Higgins, A. K., Ineson, J. R., Peel, J. S., Surlyk, F. \& Sønderholm, M. in press: The Franklinian basin in North Greenland. In Trettin, H. P. (edit.) The Innuitian Orogen and Arctic platform: Canada and Greenland. The geology of North America E. Ottawa: Geological Survey of Canada.

Hills, I. R., Whitehead, E. V., Anders, D. E., Cummins, J. J. \& Robinson, W.E. 1966: An optically active triterpane, gammacerane in Green River, Colorado, oil shale bitumen. Chem. Commun. 20, 752-754.

Horsfield, B. 1984: Pyrolysis studies and petroleum exploration. In Brooks, J. \& Welte, D. (edit.) Advances in petroleum geochemistry 1, 247-298. London: Academic Press.

Horsfield, B., Dembicki Jr, H. \& Ho, T. T. Y. 1983: Some potential applications of pyrolysis to basin studies. J. geol. Soc. Lond. 140, 431-443.

Huang, W.-Y. \& Meinschein, W. G. 1976: Sterols as ecological indicators. Geochim. cosmochim. Acta 40, 323-330.

Hunt, J. M. 1979: Petroleum geochemistry and geology, 615 pp. San Francisco: W. H. Freeman and Co.

Hurford, A. J. 1986: Cooling and uplift patterns in the Lepontine Alps, South Central Switzerland and an age of the vertical movement on the Insubric fault line. Contrib. Miner. Petrol. 92, 413-427.

Hurford, A. J. \& Green, P. F. 1983: The zeta age calibration of fission track dating. Isotope Geosci. 1, 285-317.

Hurst, J. M. 1980a: Silurian stratigraphy and facies distribution in Washington Land and western Hall Land, North Greenland. Bull. Grønlands geol. Unders. 138, 95 pp.

Hurst, J. M. 1980b: Paleogeographic and stratigraphic differentiation of Silurian buildups and biostromes of North Greenland. Bull. Am. Ass. Petrol. Geol. 64, 527-548.

Hurst, J. M. 1981: Platform edge and slope relationships:
Silurian of Washington Land, North Greenland and comparison to Arctic Canada. Bull. Can. Petrol. Geol. 29, 408-419.

Hurst, J. M. 1984: Upper Ordovician and Silurian carbonate shelf stratigraphy, facies and evolution, eastern North Greenland. Bull. Grønlands geol. Unders. 148, 73 pp.

Hurst, J. M. \& Peel, J. S. 1979: Late Proterozoic (?) to Silurian stratigraphy of southern Wulff Land, North Greenland. Rapp. Grønlands geol. Unders. 91, 37-56.

Hurst, J. M. \& Surlyk, F. 1982: Stratigraphy of the Silurian turbidite sequence of North Greenland. Bull. Grønlands geol. Unders. 145, $121 \mathrm{pp}$.

Hurst, J. M. \& Surlyk, F. 1983: Initiation, evolution and destruction of an early Paleozoic carbonate shelf, eastern North Greenland. J. Geol. 91, 671-691.

Hurst, J. M., McKerrow, W. S., Soper, N. J. \& Surlyk, F. 1983: The relationship between Caledonian nappe tectonics and Silurian turbidite deposition in North Greenland. $J$. geol. Soc. Lond. 140, 123-132.

Illich, H. A. 1983: Pristane, phytane, and lower molecular weight isoprenoid distributions in oils. Bull. Am. Ass. Petrol. Geol. 67, 385-397.

Ineson, J. R. 1985: The stratigraphy and sedimentology of the Brønlund Fjord and Tavsen Iskappe Groups (Cambrian) of Peary Land, eastern North Greenland. Unpublished Ph.D. thesis, University of Keele, U.K., $310 \mathrm{pp}$.

Ineson, J. R. \& Peel, J. S. 1980: Cambrian stratigraphy in Peary Land, eastern North Greenland. Rapp. Gronlands geol. Unders. 99, $33-42$.

Ineson, J. R. \& Peel, J. S. 1987: Cambrian platform - outer shelf relationship in the Nordenskiöld Fjord region, central North Greenland. Rapp. Grønlands geol. Unders. 133, 13-26.

Ineson, J. R. \& Peel, J. S. in press: Cambrian shelf stratigraphy of the Peary Land region, central North Greenland. Bull. Grønlands geol. Unders.

Jacob, H. 1983: Recent studies on the genesis of natural solid oil bitumens. Geol. Jahr. Reihe D 59,61 pp.

Jacob, H. 1985: Disperse, feste Erdölbitumina als Migrationsund Maturitätsindikatoren im Rahmen der Erdöl-/ErdgasProspektion. Eine Modellstudie in NW-Deutschland. Deutsche Gesellschaft Mineralölwissenschaft und Kohlechemie E.V., Forschungsbericht 267, $54 \mathrm{pp}$.

Jensenius, J. 1987: Fluid inclusion and stable isotope studies of diagenctic calcite and dolomite associated with seeping asphalt, North Greenland, 28 pp. In Jensenius, J. 1987: Fluid inclusion microthermometry and stable isotope studies applied to the diagenesis of sedimentary rocks. Unpublished lic. scient. thesis, University of Copenhagen.

Jepsen, H. F. 1971: The Precambrian, Eocambrian and early Palaezoic stratigraphy of the Jørgen Brønlund Fjord area, Peary Land, North Greenland. Bull. Grønlands geol. Unders. 96, 42 pp.

Jones, R. W. 1987: Organic facies. In Brooks, J. (edit.) Advances in petroleum geochemistry 2, 1-90. London: Academic Press.

Katz, B. J. 1983: Limitations of 'Rock-Eval' pyrolysis for typing organic matter. Org. Geochem. 4, 195-199.

Kerr, J. W. 1967: Nares submarine rift valley and relative 
rotation of North Greenland. Bull. Can. Petrol. Geol. 15, 483-520.

Kerr, J. W. 1980: A plate tectonic contest in Arctic Canada. In Strangway, D. W. (edit.) The continental crust and its mineral deposits. Spec. Pap. geol. Ass. Can. 20, 457-486.

Kingston, D. R., Dishroon, C. P. \& Williams, P. A. 1985: Global basin classification system. Oil Gas J. 83(18), 238262.

Kisch, H. J. 1980: Incipient metamorphism of Cambro-Silurian clastic rocks from the Jamtland Supergroup, central Scandinavian caledonides, western Sweden: illite crystallinite and 'vitrinite' reflectance. J. geol. Soc. Lond. 137, 271-288.

Klemme, H. D. 1971: What giants and their basins have in common. Oil Gas J. 69(9), 85-90.

Koch, C. J. W. 1987: Preparation and characterization by $\mathrm{X}$-ray diffraction of kerogen from Cambrian and Silurian sedimentary rocks from North Greenland. Unpubl. intern. GGU rep., 13 pp.

Koch, L. 1925: The geology of North Greenland. Am. J. Sci. 9, 271-285.

Koch, L. 1929: Stratigraphy of Greenland. Meddr Grønland 73(2), 205-320.

Kontorovich, A. E. 1984: Geochemical methods for the quantitative evaluation of the petroleum potential of sedimentary basins. In Demaison, G. \& Murris, R. J. (edit.) Petroleum geochemistry and basin evaluation. Mem. Am. Ass. Petrol. Geol. 35, 79-109.

Krebs, W. \& Macqueen, R. W. 1984: Sequence of diagenetic and mineralization events, Pine-Point lead-zinc property, Northwest Territories, Canada. Bull. Can. Petrol. Geol. 32, 434-464.

Larsen, N. H. 1985: Cambrian endolithic alga from North Greenland. Sec. Int. Phycol. Congr., Book of abstracts, 88. Copenhagen.

Larsen, N. H. 1989: Fossil algae from North Greenland. Open File Ser. Grønlands geol. Unders. 89/3, 32 pp. +42 figs.

Larsen, O. 1982: The age of the Kap Washington Group volcanics, North Greenland. Bull. geol. Soc. Denmark 31, 49-55.

Larsen, O., Dawes, P. R. \& Soper, N. J. 1978: Rb/Sr age of the Kap Washington Group, Peary Land, North Greenland, and its geotectonic implications. Rapp. Grønlands geol. Unders. 90, 115-119.

Larsen, P.-H. \& Escher, J. C. 1985: The Silurian turbidite sequence of the Peary Land Group between Newman Bugt and Victoria Fjord, western North Greenland. Rapp. Grønlands geol. Unders. 126, 47-67.

Larsen, P.-H. \& Escher, J. C. 1987: Additions to the lithostratigraphy of the Peary Land Group (Silurian) in western and central North Greenland. Rapp. Gronlands geol. Unders. 133, 65-80.

Larsen, P.-H., Edwards, D. \& Escher, J. C. 1987: Late Silurian plant megafossils from the Peary Land Group, North Greenland. Rapp. Grønlands geol. Unders. 133, 107-112.

Legall, F. D., Barnes, C. R. \& Macqueen, R. W. 1981: Thermal maturation, burial history and hotspot development, Paleozoic strata of southern Ontario-Québec, from cono- dont and acritarch colour alteration studies. Bull. Can. Petrol. Geol. 29, 492-539.

Leggett, J. K., McKerrow, W. S., Cocks, L. R. M. \& Richards, R. B. 1981: Perodicity in the early Palaeozoic marine realm. J. geol. Soc. Lond. 138, 167-176.

Lewan, M. D. 1983: Effects of thermal maturation on stable organic carbon isotopes as determined by hydrous pyrolysis of Woodford Shale. Geochim. cosmochim. Acta 47, 14711479.

Lewan, M. D. 1986: Stable carbon isotopes of amorphous kerogens from Phanerozoic rocks. Geochim. cosmochim. Acta 50, 1583-1591.

Leythaeuser, D. 1973: Effects of weathering on organic matter in shales. Geochim. cosmochim. Acta 37, 113-120.

Link, W. K. 1952: Significance of oil and gas seeps in World oil exploration. Bull. Am. Ass. Petrol. Geol. 36, 1505-1540.

Macauley, G., Snowdon, L. R. \& Ball, F. D. 1985: Geochemistry and geological factors governing exploitation of selected Canadian oil shale deposits. Pap. geol. Surv. Can. 85-13, 65 pp.

Mackenzie, A. G. 1984: Applications of biological markers in petroleum geochemistry. In Brooks, J. \& Welte, D. H. (edit.) Advances in petroleum geochemistry 1, 115-214. London: Academic Press.

Macqueen, R. W. \& Powell, T. G. 1983: Organic geochemistry of the Pine Point lead-zinc ore field and region, Northwest Territories, Canada. Econ. Geol. 78, 1-15.

Marcussen, C., Christiansen, F. G., Larsen, P.-H., Olsen, H., Piasecki, S., Stemmerik, L., Bojesen-Koefoed, J., Jepsen, H. F. \& Nøhr-Hansen, H. 1987: Studies of the onshore hydrocarbon potential in East Greenland 1986-87: field work from $72^{\circ}$ to $74^{\circ} \mathrm{N}$. Rapp. Grønlands geol. Unders. 135, 72-81.

McKerrow, W. S. 1979: Ordovician and Silurian changes in sea level. J. geol. Soc. Lond. 136, 137-145.

McKirdy, D. M., Aldridge, A. K. \& Ypma, P. J. M. 1983: A geochemical comparison of some crude oils from Pre-Ordovician carbonate rocks. In Bjoroy, M. et al. (edit.) Advances in organic geochemistry 1981, 99-107. London: Wiley \& Sons Ltd.

McKirdy, D. M., Kantsler, A. J., Emmett, J. K. \& Aldridge, A. K. 1984: Hydrocarbon genesis and organic facies in Cambrian carbonates of the eastern Officer basin, South Australia. In Palacas, J. G. (edit.) Petroleum geochemistry and source rock potential of carbonate rocks. Am. Ass. Petrol. Geol. Stud. Geol. 18, 13-31.

Miller, B. M. 1986: Resource appraisal methods, choice and outcome. In Rice, D. D. (edit.) Oil and gas assessment. Am. Ass. Petrol. Geol. Stud. Geol. 21, 1-23.

Moldowan, J. M. Seifert, W. K. \& Gallegos, E. J. 1985: Relationship between petroleum composition and depositional environment of petroleum source rocks. Bull. Am. Ass. Petrol. Geol. 69, 1255-1268.

Moore, L. V. 1984: Significance, classification of asphaltic material in petroleum exploration. Oil Gas J. 82(41), 109 112 .

Nassichuk, W. W. 1983: Petroleum potential in Arctic North 
America and Greenland. Cold Regions Science and Technology 7, 51-88.

Nielsen, E. 1941: Remarks on the map and the geology of Kronprins Christians Land. Meddr Grønland 126(2), 34 pp.

Norford, B. S. 1972: Silurian stratigraphic sections at Kap Tyson, Offley $\emptyset$ and Kap Schuchert, northwestern Greenland. Meddr Grønland 195(2), 40 pp.

Nøhr-Hansen, H. \& Koppelhus, E. B. 1988: Ordovician spores with trilete rays from Washington Land, North Greenland. Rev. Palaeobot. Palynol. 56, 305-311.

O'Connor, B. 1979: The Portfjeld Formation (?early Cambrian) of eastern North Greenland. Rapp. Grønlands geol. Unders. 88, 23-28.

Ogunyami, O., Hesse, R. \& Héroux, Y. 1980: Pre-orogenic and synorogenic diagenesis and anchimetamorphism in Lower Paleozoic continental margin sequences of the northern Appalachians in and around Quebec City, Canada. Bull. Can. Petrol. Geol. 28, 559-577.

Ourisson, G., Albrecht, P. \& Rohmer, M. 1979: Paleochemistry and biochemistry of a group of natural products: the hopanoids. Pure Appl. Chem. 51, 709-729.

Østfeldt, P. 1987a: Oil-source rock correlation in the Danish North Sea. In Brooks, J. \& Glennie, K. (edit.): Petroleum geology of North West Europe, 419-429. London: Graham \& Trotman.

Østfeldt, P. 1987b: Organic geochemistry of North Greenland samples. Unpubl. intern. GGU rep., 43 pp.

Parrish, J. T. 1982: Upwelling and petroleum source beds, with reference to Paleozoic. Bull. Am. Ass. Petrol. Geol. 66, $750-774$.

Parrish, J. T. 1987: Palaeo-upwelling and the distribution of organic-rich rocks. In Brooks, J. \& Fleet, A. J. (edit.) Marine petroleum source rocks. Spec. Publ. geol. Soc. Lond. 26, 199-205.

Peel, J. S. 1979: Cambrian-Middle Ordovician stratigraphy of the Adams Gletscher region, south-west Peary Land, North Greenland. Rapp. Grønlands geol. Unders. 88, 29-39.

Peel, J. S. 1980: Cambrian and Ordovician geology of Warming Land and southern Wulff Land, central North Greenland. Rapp. Grønlands geol. Unders. 101, 55-60.

Peel, J. S. 1982: The Lower Paleozoic of Greenland. In Embry, A. F. \& Balkwill, H. R. (edit.) Arctic geology and geophysics. Mem. Can. Soc. Petrol. Geol. 8, 309-330.

Peel, J. S. 1985: Cambrian - Silurian platform stratigraphy of eastern North Greenland. In Gee, D. G. \& Sturt, B. A. (edit.) The Caledonide Orogen - Scandinavia and related areas, 1077-1094. London: John Wiley \& Sons Ltd.

Peel, J. S. \& Christie, R. L. 1982: Cambrian-Ordovician stratigraphy, correlations around Kane basin. In Dawes, P. R. \& Kerr, J. W. (edit.) Nares Strait and the drift of Greenland: a conflict in plate tectonics. Meddr Grønland Geosci. 8, 117135.

Peel, J. S. \& Hurst, J. M. 1980: Late Ordovician and early Silurian stratigraphy of Washington Land, western North Greenland. Rapp. Gronlands geol. Unders. 100, 18-24.

Peel, J. S. \& Wright, S. C. 1985: Cambrian platform stratigraphy in the Warming Land - Freuchen Land region, North Greenland. Rapp. Grønlands geol. Unders. 126, 17-24.
Peel, J. S., Dawes, P. R., Collinson, J. D. \& Christie, R.L. 1982: Proterozoic - basal Cambrian stratigraphy across Nares Strait: correlation between Inglefield Land and Bache Peninsula. In Dawes, P. R. \& Kerr, J. W. (edit.) Nares Strait and the drift of Greenland: a conflict in plate tectonics. Meddr Grønland Geosci. 8, 105-115.

Perregaard, J. 1979: Organic geochemistry of sedimentary organic matter from Greenland: a petroleum source rock evaluation. Unpubl. intern. GGU rep., 81 pp. + appendix.

Philp, R. P. \& Lewis, C. A. 1987: Organic geochemistry of biomarkers. Ann. Rev. Earth Planet. Sci. 15, 363-395.

Poty, B., Leroy, J. \& Jachimowicz, 1976: A new device for measuring temperatures under microscope: the Chaixmeca microthermometry apparatus. In Roedder, E. \& Kozlowski, A. (edit) Fluid inclusion research 9, 173-178.

Powell, T. G. 1978: An assessment of the hydrocarbon source potential of the Canadian Arctic Island. Pap. geol. Surv. Can. 78-12, 82 pp.

Powell, T. G., Macqueen, R. W., Barker, J. F. \& Bree, D. G. 1984: Geochemical character and origin of Ontario oils. Bull. Can. Petrol. Geol. 32, 289-312.

Procter, R. M., Tayor, G. C. \& Wade, J. A. 1984: Oil and gas resources of Canada. Pap. geol. Surv. Can. 83-31, 59 pp.

Radke, B. M. \& Mathis, R. L. 1980: On the formation and occurrence of saddle dolomite. J. sed. Petrol. 50, 1149-1168.

Rayer, F. G. 1981: Exploration prospects and future petroleum potential of the Canadian Arctic Islands. J. petrol. Geol. 3, $367-412$.

Reed, J. D., Illich, H. A. \& Horsfield, B. 1986: Biochemical evolutionary significance of Ordovician oils and their sources. In Leythaeuser, D. \& Rullkötter, J. (edit.) Advances in organic geochemistry 1985. Org. Geochem. 10, 347-358.

Rice, D. D. (edit.) 1986: Oil and gas assessment. Am. Ass. Petrol. Geol. Stud. Geol. 21, 267 pp.

Robert, P. 1974: Analyse microscopique des charbons et des bitumen dispersés dans roches et mesure de leur pouvoir réflecteur. Application à l'étude de la paléogéothermie des bassins sédimentaires et de la genèse des hydrocarbures. In Tissot, B. \& Bienner, F. (edit.) Advanced organic geochemistry, 549-569. Rueil-Malmaison.

Rogers, M. A., McAlary, J. D. \& Baily, N. J. L. 1974: Significance of reservoir bitumens to thermal-maturation studies, Western Canada basin. Bull. Am. Ass. Petrol. Geol. 58, 1806-1824.

Rolle, F. 1981: Hydrocarbon source rock sampling in Peary Land 1980. Rapp. Grønlands geol. Unders. 106, 99-103.

Rolle, F. \& Wrang, P. 1981: En foreløbig oliegeologisk vurdering af Peary Land området i Nordgrønland. Unpubl. intern. GGU rep., 21 pp.

Rullkötter, J., Meyers, P. A., Schaefer, R. G. \& Dunham, K. W. 1986: Oil generation in the Michigan Basin: a biological marker and carbon isotope approach. In Leythaeuser, D. \& Rullkötter, J. (edit.) Advances in organic geochemistry 1985. Org. Geochem. 10, 359-375.

St. John, B., Bally, A. W. \& Klemme, H. D. 1984: Sedimentary provinces of the world - hydrocarbon productive 
and nonproductive. Am. Assoc. Petrol. Geol. Map Library, 36 pp. + maps.

Schoell, M. 1984: Wasserstoff- und Kohlenstoffisotope in organischen Substanzen, Erdölen und Erdgassen. Geol Jahrb. Reihe D. 67, 167 pp.

Schopf, T. J. M. 1983: Paleozoic black shales in relation to continental margin upwelling. In Thiede, J. \& Suess, E. (edit.) Coastal upwelling, its sediment record, part B: Sedimentary records of ancient coastal upwelling, 570-596. New York: Plenum Press.

Scotese, C. R., Bambach, R. K., Barton, C., Van der Voo, R. \& Ziegler, A. M. 1979: Palaeozoic base maps. J. Geol. 87 , 217-278.

Sikander, A. H. \& Pittion, J. L. 1978: Reflectance studies on organic matter in Lower Paleozoic sediments of Quebec. Bull. Can. Petrol. Geol. 26, 132-151.

Sluijk, D. \& Nederlof, M. H. 1984: Worldwide geological experience as a systematic basis for prospect appraisal. In Demaison, G. \& Murris, R. J. (edit.) Petroleum geochemistry and basin evaluation. Mem. Am. Ass. Petrol. Geol. 35, 15-26.

Smith, M. P., Sønderholm, M. \& Tull, S. J. 1989: The Morris Bugt Group (Middle Ordovician - Early Silurian) of North Greenland and its correlatives. Rapp. Grønlands geol. Unders. 143.

Sønderholm, M. \& Due, P. H. 1985: Lower and Middle Ordovician platform carbonate lithostratigraphy of Warming Land, Wulff Land and Nares Land, North Greenland. Rapp. Grønlands geol. Unders. 126, 31-46.

Sønderholm, M. \& Harland, T. L. 1989a: Franklinian reef belt, Silurian, North Greenland. In Geldsetzer, H. J. J., James, N. P. \& Tebbutt, G. E. (edit.) Reefs, Canada and adjacent area. Mem. Can. Soc. Petrol. Geol. 13, 356-366.

Sønderholm, M. \& Harland, T. L. 1989b: Latest Ordovicianearliest Silurian reef mounds in western North Greenland. In Geldsetzer, H. J. J., James, N. P. \& Tebbutt, G. E. (edit.) Reefs, Canada and adjacent area. Mem. Can. Soc. Petrol. Geol. 13, 241-243.

Sønderholm, M., Harland, T. L., Due, P. H., Jørgensen, L. N. \& Peel, J. S. 1987: Lithostratigraphy and depositional history of Upper Ordovician - Silurian shelf carbonates in central and western North Greenland. Rapp. Grønlands geol. Unders. 133, 27-40.

Soper, N. J. \& Higgins, A. K. 1987: A shallow detachment beneath the North Greenland fold belt: implications for sedimentation and tectonics. Geol. Mag. 124, 441-450.

Soper, N. J., Dawes, P. R. \& Higgins, A. K. 1982: CretaceousTertiary magmatic and tectonic events in North Greenland and the history of adjacent ocean basins. In Dawes, P. R. \& Kerr, J. W. (edit.) Nares Strait and the drift of Greenland: a conflict in plate tectonics. Meddr Grønland Geosci. 8, 205220.

Springer, N. 1981: Preliminary Rb-Sr age determinations from the North Greenland fold belt, Johannes V. Jensen Land, with comments on the metamorphic grade. Rapp. Grønlands geol. Unders. 106, 77-84.

Springer, N. (compiler) 1987: Conventional core analysis for
GGU. Cambrian sandstones from North Greenland (Nordolie). Unpubl. intern. GGU rep., 17 pp.

Sproule, J. C. 1966: Oil and gas prospects of the Canadian Arctic Islands. Proc. 8th Commonwealth Mining and Metallurgical Congress, Australia and New Zealand 1965, Vol. 5 (Petroleum), 57-64.

Staplin, F. L. 1969: Sedimentary organic matter, organic metamorphism, and oil and gas occurrence. Bull. Can. Soc. Petrol. Geol. 17, 47-66.

Stemmerik, L. \& Håkansson, E. 1989: Stratigraphy and depositional history of the Upper Palaeozoic and Triassic sediments in the Wandel Sea Basin, eastern North Greenland. Rapp. Grønlands geol. Unders. 143.

Stoneley, R. 1981: Petroleum: the sedimentary basin. In Tarling, D. H. (edit.) Economic geology and geotectonics, 51-71. London: John Wiley \& Sons Ltd.

Stouge, S., Thomsen, E. \& Guvad, C. 1988: Reflected light microscopy of graptolite periderm material of Ordovician/ Silurian strata in North Greenland. Unpubl. intern. GGU rep., 58 pp.

Strother, P. K. \& Traverse, A. 1979: Plant microfossils from Llandoverian and Wenlockian rocks of Pennsylvania. Palynology 3, 1-21.

Stuart-Smith, J. H. 1970: Hydrocarbon potential of northern Greenland. Bull. Am. Ass. Petrol. Geol. 54, 2507 only.

Stuart-Smith, J. H. \& Wennekers, J. H. N. 1977: Geology and hydrocarbon discoveries of Canadian Arctic Islands. Bull. Am. Ass. Petrol. Geol. 61, 1-27.

Surlyk, F. 1982: Nares Strait and the down-current termination of the Silurian turbidite basin of North Greenland. In Dawes, P. R. \& Kerr, J. W. (edit.) Nares Strait and the drift of Greenland: a conflict in plate tectonics. Meddr Grønland Geosci. 8, 147-150.

Surlyk, F. 1983: Source rock sampling, stratigraphical and sedimentological studies in the Upper Palaeozoic of the Jameson Land basin, East Greenland. Rapp. Grønlands geol. Unders. 115, 88-93.

Surlyk, F. \& Hurst, J. M. 1983: Evolution of the early Paleozoic deep-water basin of North Greenland - aulacogen or narrow ocean? Geology 11, 77-81.

Surlyk, F. \& Hurst, J. M. 1984: The evolution of the early Paleozoic deep-water basin of North Greenland. Bull. geol. Soc. Am. 95, 131-154.

Surlyk, F., Hurst, J. M., Marcussen, C., Piasecki, S., Rolle, F., Scholle, P. A., Stemmerik, L. \& Thomsen, E. 1984: Oil geological studies in the Jameson Land basin, East Greenland. Rapp. Grønlands geol. Unders. 120, 85-90.

Surlyk, F. \& Ineson, J. R. 1987a: Aspects of Franklinian shelf, slope and trough evolution and stratigraphy of North Greenland. Rapp. Gronlands geol. Unders. 133, 41-58.

Surlyk, F. \& Ineson, J. R. 1987b: The Navarana Fjord Member (new) - an Upper Llandovery platform derived carbonate conglomerate. Rapp. Grønlands geol. Unders. 133, 59-63.

Thickpenny, A. \& Leggett, J. K. 1987: Stratigraphic distribution and palaeo-oceanographic significance of European early Palaeozoic organic-rich sediments. In Brooks, J. \& 
Fleet, A. J. (edit.) Marine petroleum source rocks. Spec. Publ. geol. Soc. Lond. 26, 231-247.

Thomsen, E. \& Guvad, C. 1987: Organic petrology and thermal maturity of Lower Palaeozoic deposits from western and central North Greenland. Unpubl. intern. GGU rep., part 1 (text) $40 \mathrm{pp}$. and part 2 (figures) $49 \mathrm{pp}$

Tissot, B. P. \& Welte D. H. 1984: Petroleum formation and occurrence, 699 pp. Berlin, Heidelberg, New York, Tokyo: Springer Verlag.

Trettin, H. P. 1987: Pearya: a composite terrane with Caledonian affinities in northern Ellesmere Island. Can. J. Earth Sci. 24, 224-245.

Trettin, H. P. \& Balkwill, H. R. 1979: Contributions to the tectonic history of the Innuitian Province, Arctic Canada. Can. J. Earth Sci. 16, 748-769.

Trettin, H. P., Frisch, T. O., Sobczak, L. W., Weber, J. R., Law, L. R., Delaurier, I., Niblett, E. R. \& Whitnam, K. 1972: The Innuitian Province. In Price, R. A. \& Douglas, R. J. W. (edit.) Variation in tectonic styles in Canada. Spec. Pap. geol. Ass. Can. 11, 83-179.

Troelsen, J. C. 1949: Contributions to the geology of the area round Jørgen Brønlunds Fjord, Peary Land, North Greenland. Meddr Grønland 149(2), 29 pp.

Troelsen, J. C. 1950: Contributions to the geology of Northwest Greenland, Ellesmere Island and Axel Heiberg Island. Meddr Grønland 149(7), 85 pp.

Tyson, R. V. 1987: The genesis and palynofacies characteristics of marine petroleum source rocks. In Brooks, J. \& Fleet, A. J. (edit.) Marine petroleum source rocks. Spec. Publ. geol. Soc. Lond. 26, 47-67.
Ungerer, P., Bessis, F., Chenet, P. Y., Durand, B., Nogaret, A., Chiarelli, A., Oudin, J. L. \& Perrin, J. F. 1984: Geological and geochemical models in oil exploration; principles and practical examples. In Demaison, G. \& Murris, R. J. (edit.) Petroleum geochemistry and basin evaluation. Mem. Am. Ass. Petrol. Geol. 35, 53-77.

Vavrdová, N. 1984: Some plant microfossils of possible terrestrial origin from the Ordovician of Central Bohemia. Věstnik Ústředniho ústavu geologického 59, 165-170.

Venkatachala, B. S. 1981: Differentiation of amorphous organic matter types in sediments. In Brooks, J. (edit.) Organic maturation studies and fossil fuel exploration, 177-200. London: Academic Press.

Waples, D. W. 1985: Geochemistry in petroleum exploration, 232 pp. Dordrecht: Reidel Publ. Com.

Wedeking, K. W. \& Hayes, J. M. 1983: Carbonization of Precambrian kerogens. In Bjorøy et al. (edit.) Advances in organic geochemistry 1981, 546-553. London: Wiley \& Sons Ltd.

Welte, D. H., Kalkreuth, W. \& Hoefs, J. 1975: Age-trend in carbon isotopic composition in Palaeozoic sediments. Naturwissenschaften 62, 482-483.

Welte, D. H. \& Yukler, M. A. 1981: Petroleum origin and accumulation in basin evolution - a quantitative model. Bull. Am. Ass. Petrol. Geol. 65, 1387-1396.

Yarbrough, S. C. 1986: Oil and gas developments in Europe 1985. Bull. Am. Ass. Petrol. Geol. 70, 1578-1610. 
Plate 1. Kerogen

A. Sample with a relatively low $(0.21 \%$ TOC) kerogen content and a dominance of finely disseminated amorphous kerogen in a silica gel, Lafayette Bugt Formation, Nyeboe Land, GGU 316490-1, unsieved organic material.

B. As A., Lafayette Bugt Formation, Nyeboe Land, GGU $316490-2$, sieved organic material (on $10 \mu \mathrm{m}$ nylon mesh).

C. Sample with a relatively moderate $(1.15 \%$ TOC) kerogen content and small to moderate amounts of large amorphous kerogen particles, Thors Fjord Member, Nares Land, GGU 318007-18-1 unsieved organic material.

\section{Plate 2. Cambrian palynomorphs}

A. Acritarch-like folded alga. Middle Cambrian Sydpasset Formation, Freuchen Land, MGUH 19334 from GGU 315873-2; 139.5-13.9.

B. Acritarch-like folded alga. Middle Cambrian Sydpasset Formation, Freuchen Land, MGUH 19335 from GGU 315873-2; 150.6-7.0.

C. Two acritarch-like folded algae. Middle Cambrian Sydpasset Formation, Freuchen Land, MGUH 19336 (large light body), MGUH 19337 (dark small body), both from GGU 315873-2; 122.0-15.3.

D. Acritarch-like folded alga. Middle Cambrian, Ekspedition Bræ Formation, Freuchen Land, MGUH 19338 from GGU 324217-2; 139.2-14.9.

E. Acritarch-like folded alga. Middle Cambrian, Ekspedition Bræ Formation, Freuchen Land, MGUH 19339 from GGU $324300-2 ; 131.2-13.4$.

\section{Plate 3. Ordovician palynomorphs}

A. Acritarch. Upper Ordovician Troedsson Cliff Member, Washington Land, MGUH 19344 from GGU 316968-2; 145.3-17.8.

B. Acritarch. Upper Ordovician - Lower Silurian Aleqatsiaq Fjord Formation, Washington Land, MGUH 19345 from GGU $316085-4 ; 124.1-21.3$.

C. Graptolite fragment, Upper Ordovician Troedsson Cliff Member, Washington Land, MGUH 19346 from GGU 316968-2; 128.1-2.9.

D. Scolecodont, Upper Ordovician, Troedsson Cliff Member, Washington Land, MGUH 19347 from GGU 316968-2; 148.8-15.1.

E. Alga. Upper Ordovician - Lower Silurian Aleqatsiaq Formation, Nyeboe Land, MGUH 19348 from GGU 316103-2; 135.0-15.0.

F. Filamentous alga. Upper Ordovician - Lower Silurian Aleqatsiaq Formation, Washington Land, MGUH 19349 from GGU $316058-2 ; 135.1-4.2$.

\section{Plate 4. Silurian palynomorphs}

A. Chitinozoan, Angochitina cf. A. elongata. Upper Silurian Wulff Land Formation, Wulff Land, MGUH 19350 from GGU 315950-3; 136.9-17.2.

B. Chitinozoans, Linochitina erratica. Upper Silurian Wulff Land Formation, Wulff Land, MGUH 19351 from GGU 315950-2; 154.3-9.6.

C. Retiolites, graptolite fragment. Upper Silurian, Wulff Land Formation, Wulff Land, MGUH 19352 from GGU 315950-3; 155.1-11.1.

D. Graptolite fragment, Upper Silurian, Wulff Land Formation, Wulff Land, MGUH 19353 from GGU 315950-2; 127.3-5.7.

E.-H. Trilete spore-like bodies, figs $\mathrm{E}$ and $\mathrm{F}$ with a degraded bitumen-like appearance.

E. Lower Silurian Lafayette Bugt Formation, Washington Land, MGUH 19354 from GGU 211760-2; 143.3-17.2. F. Upper Silurian Wulff Land Formation, Wulff Land, MGUH 19355 from GGU 315950-3; 15950-3; 155.5-8.2.
D. As C., Thors Fjord Member, Nares Land, GGU $318007-$ $18-2$, sieved organic material (on $10 \mu \mathrm{m}$ nylon mesh).

E. Sample with a relatively large $(5.09 \%$ TOC) kerogen content and a dominance of large amorphous kerogen particles, Thors Fjord Member, Nares Land, GGU 318007-32-1, unsieved organic material.

F. As E., Thors Fjord Member, Nares Land, GGU $318007-$ $32-2$, sieved organic material (on $10 \mu \mathrm{m}$ nylon mesh).

Scale bar: $20 \mu \mathrm{m}$

F. Acritarch-like folded alga. Middle Cambrian, Ekspedition Bræ Formation, Freuchen Land, MGUH 19340 from GGU 324217-2; 141.9-11.4.

G. Lump of algal or spore-like elements. Middle Cambrian, Ekspedition Bræ Formation, Freuchen Land, MGUH 19341 from GGU 324300-2; 127.8-14.4.

H. Diad-like lump of algal or spore-like elements. Middle Cambrian, Ekspedition Bræ Formation, Freuchen Land, MGUH 19342 from GGU 314300-2; 138.5-17.8.

I. Lump of alga or spore-like elements. Middle Cambrian, Ekspedition Bræ Formation, Freuchen Land, MGUH 19343 from GGU 324300-2; 157.7-14.7.

Scale bar: $20 \mu \mathrm{m}$

G.-L. Spores with trilete rays. Upper Ordovician, Troedsson Cliff Member, Washington Land (Nøhr-Hansen \& Koppelhus, 1988).

G.-I. Besselia nunaatica, MGUH 17539 from GGU 316968-2; 125.5-8.3.

G. Distal view illustrating the minute ornamentation.

H. Equatorial view.

I. Internal proximal view.

J. Besselia nunaatica, two connected spores, internal proximal view, MGUH 17541 from GGU 316968-2; 155.1-11.9. K.-L. Besselia nunaatica. MGUH 17542 from GGU 316968-2; 123.8-15.9.

$\mathrm{K}$. Distal view illustrating the ornamentation.

L. Internal proximal view.

Scale bar: $20 \mu \mathrm{m}$

G. Upper Silurian Nyeboe Land Formation, Nyeboe Land, MGUH 19356 from GGU 319234-2; 119.3-11.0.

H. Upper Silurian Nyeboe Land Formation, Wulff Land, MGUH 19357 from GGU 319210-3; 130.6-21.4.

I. Spherical folded algae, acritarchs? Lower Silurian Lafayette Bugt Formation, Hall Land, MGUH 19358 from GGU 324157-2; 144.2-8.5.

J. Tubular structure. Upper Silurian Nyeboe Land Formation, Wulff Land, MGUH 19359 from GGU 319210-3; 146.6-16.5.

K. Tubular structure. Upper Silurian Nyeboe Land Formation, Nyeboe Land, MGUH 19360 from GGU 319234-2; 138.8-8.0.

L. Rounded drop-shaped palynomorphs. Lower Silurian Lafayette Bugt Formation, Washington Land, MGUH 19361 from GGU 316061-2; 137.1-14.8.

Scale bar: $20 \mu \mathrm{m}$. 
Plate 1. Kerogen

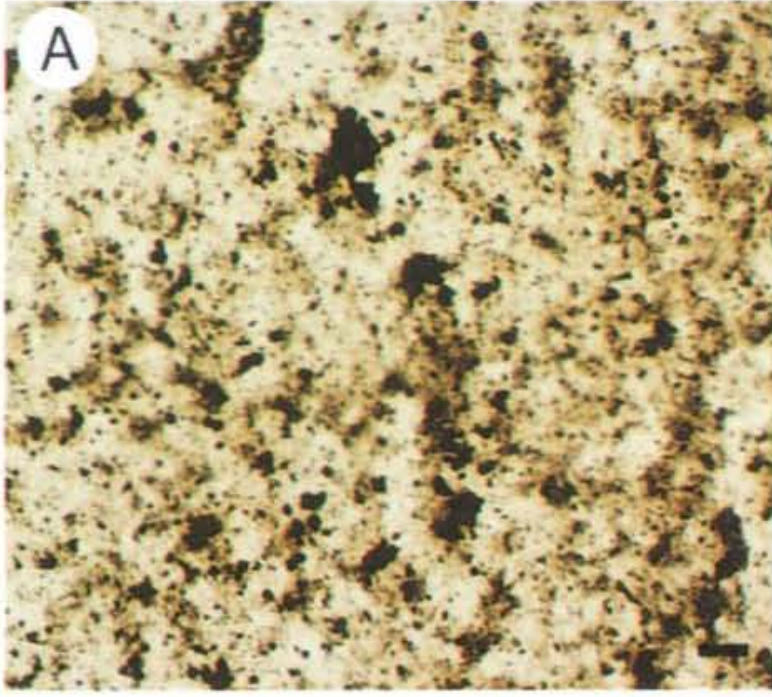

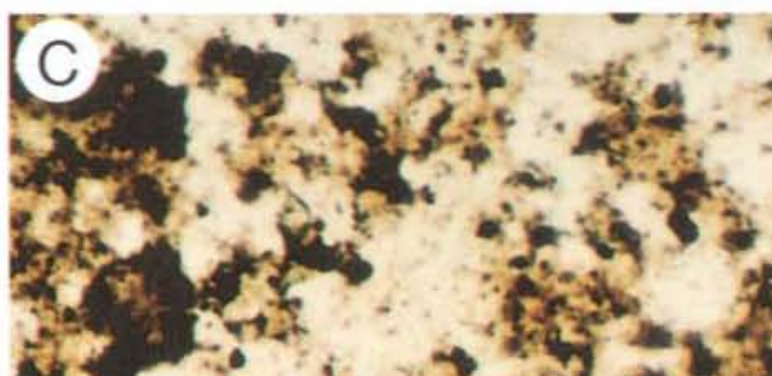

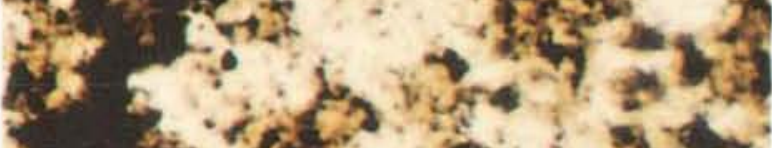

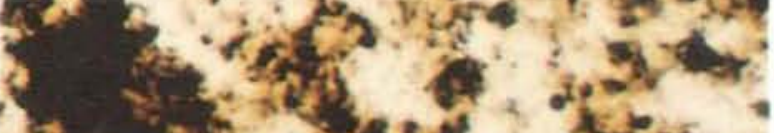

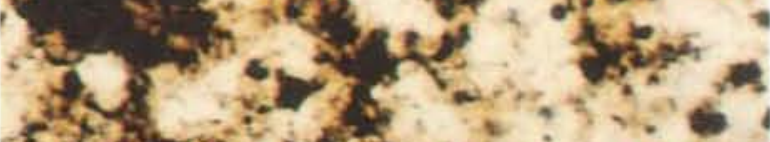
क्री

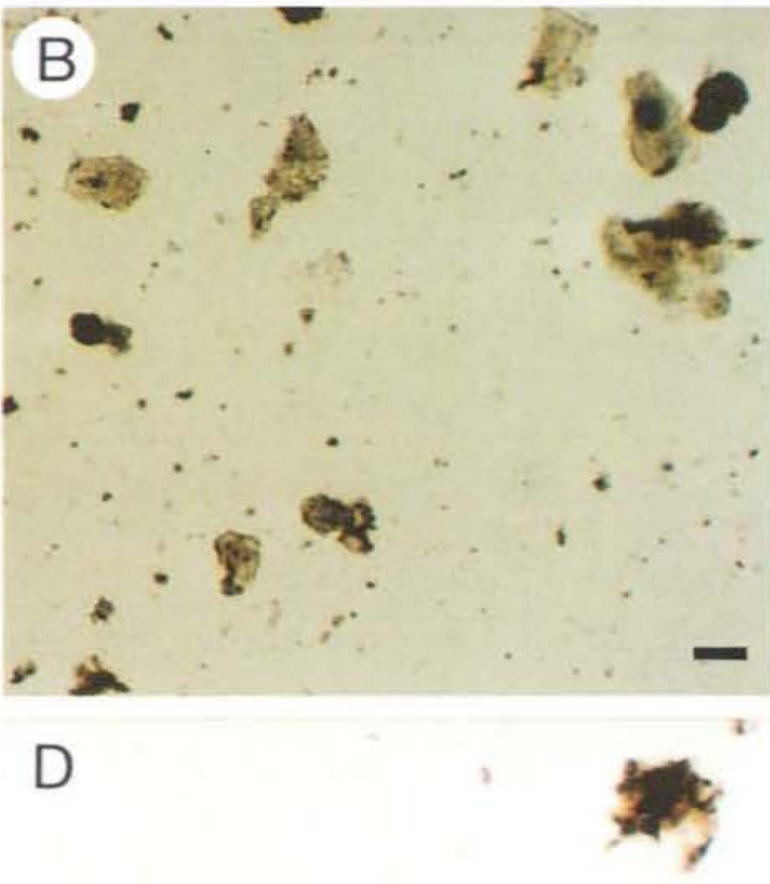

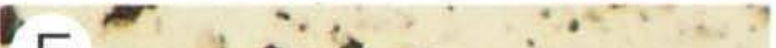
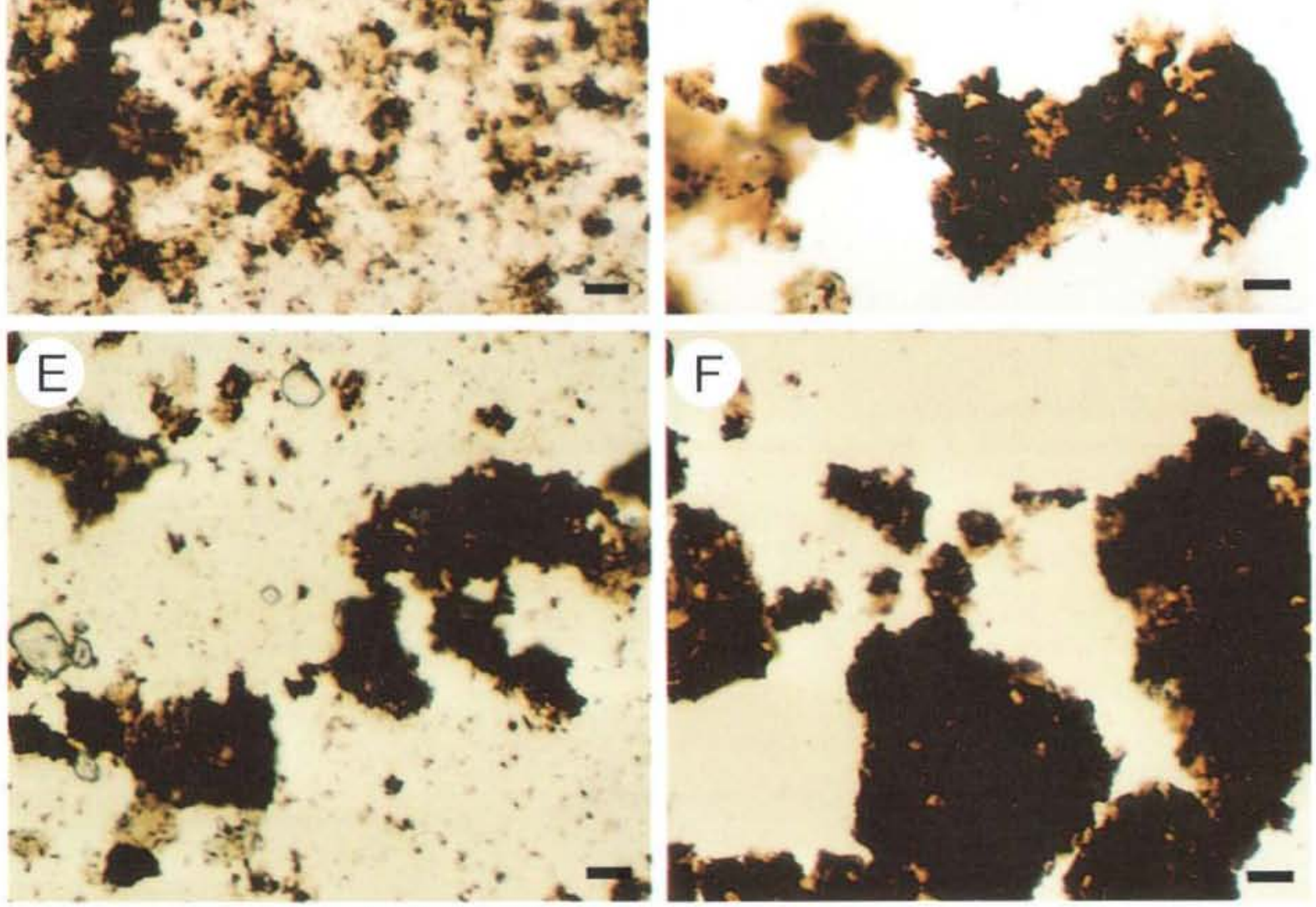
Plate 2. Cambrian palynomorphs

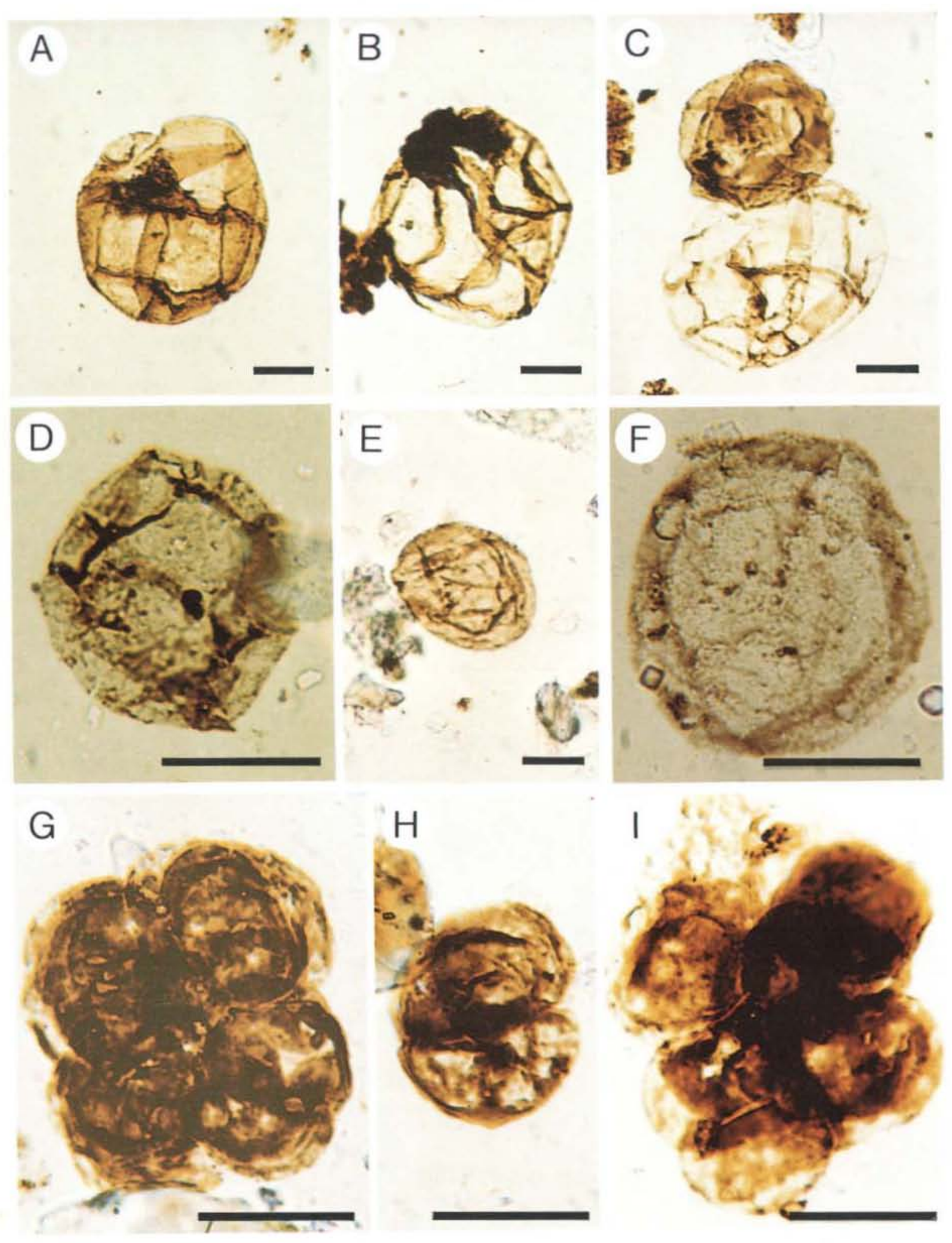


Plate 3. Ordovician palynomorphs
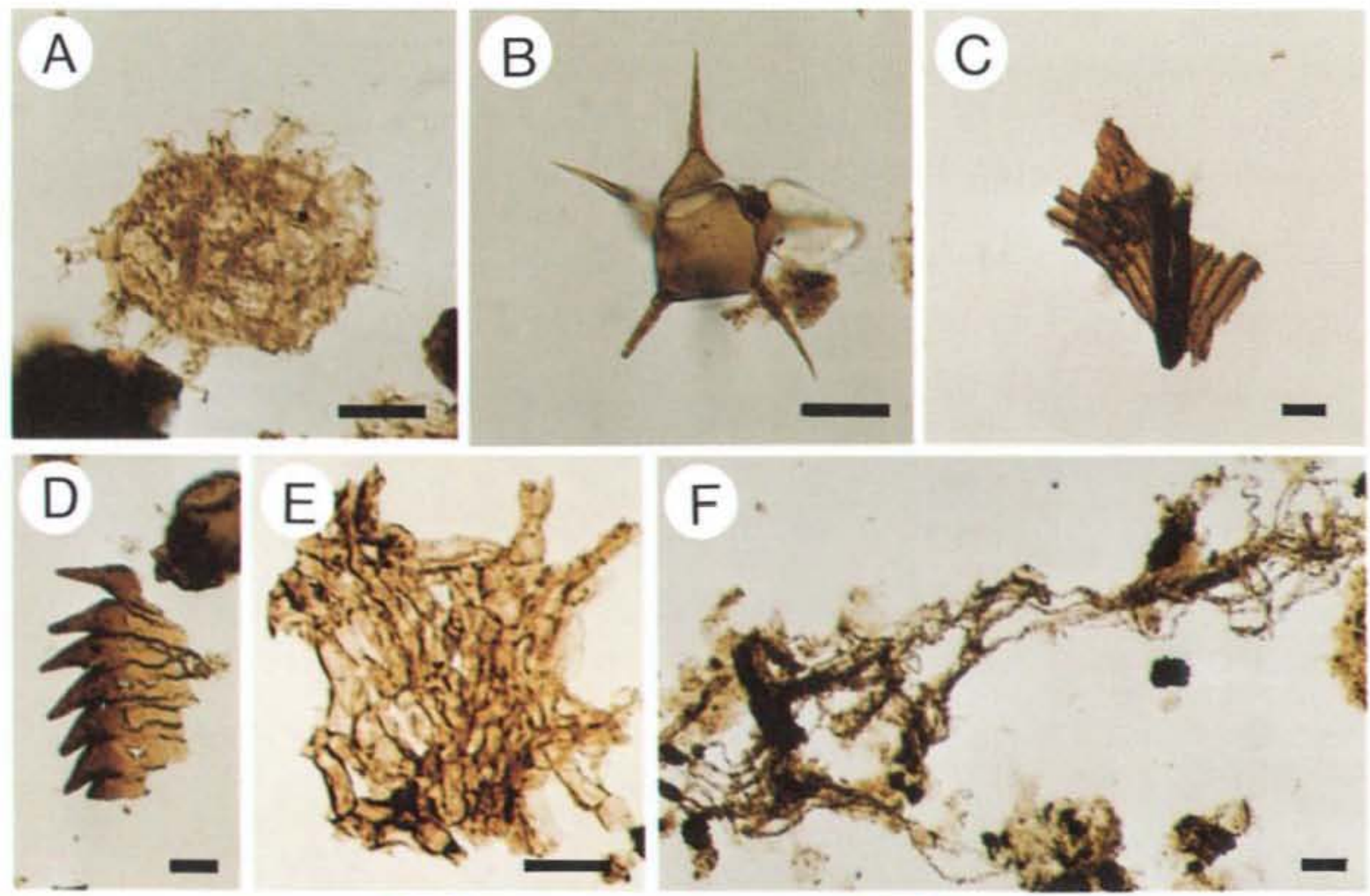

G
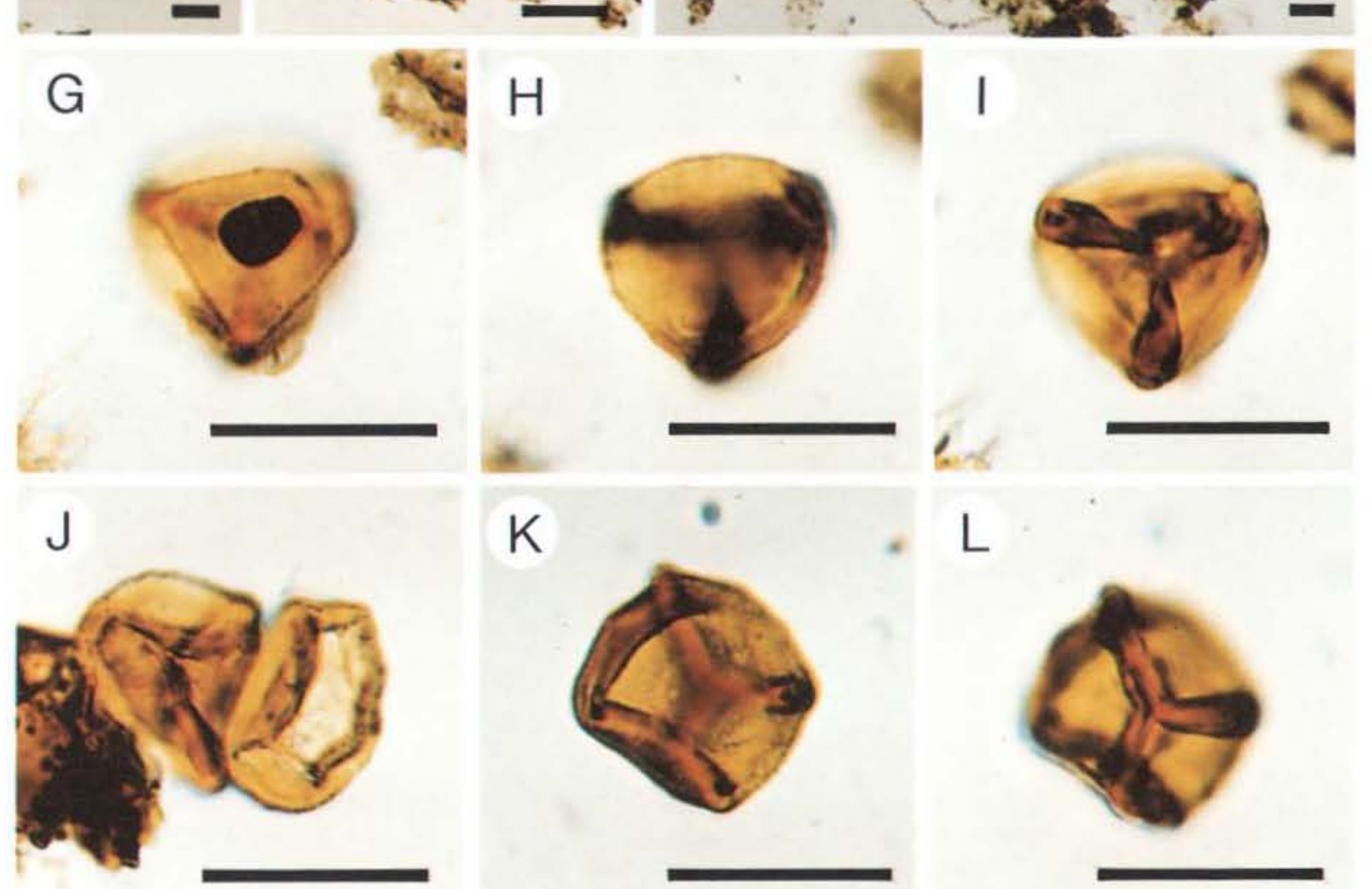
Plate 4. Silurian palynomorphs

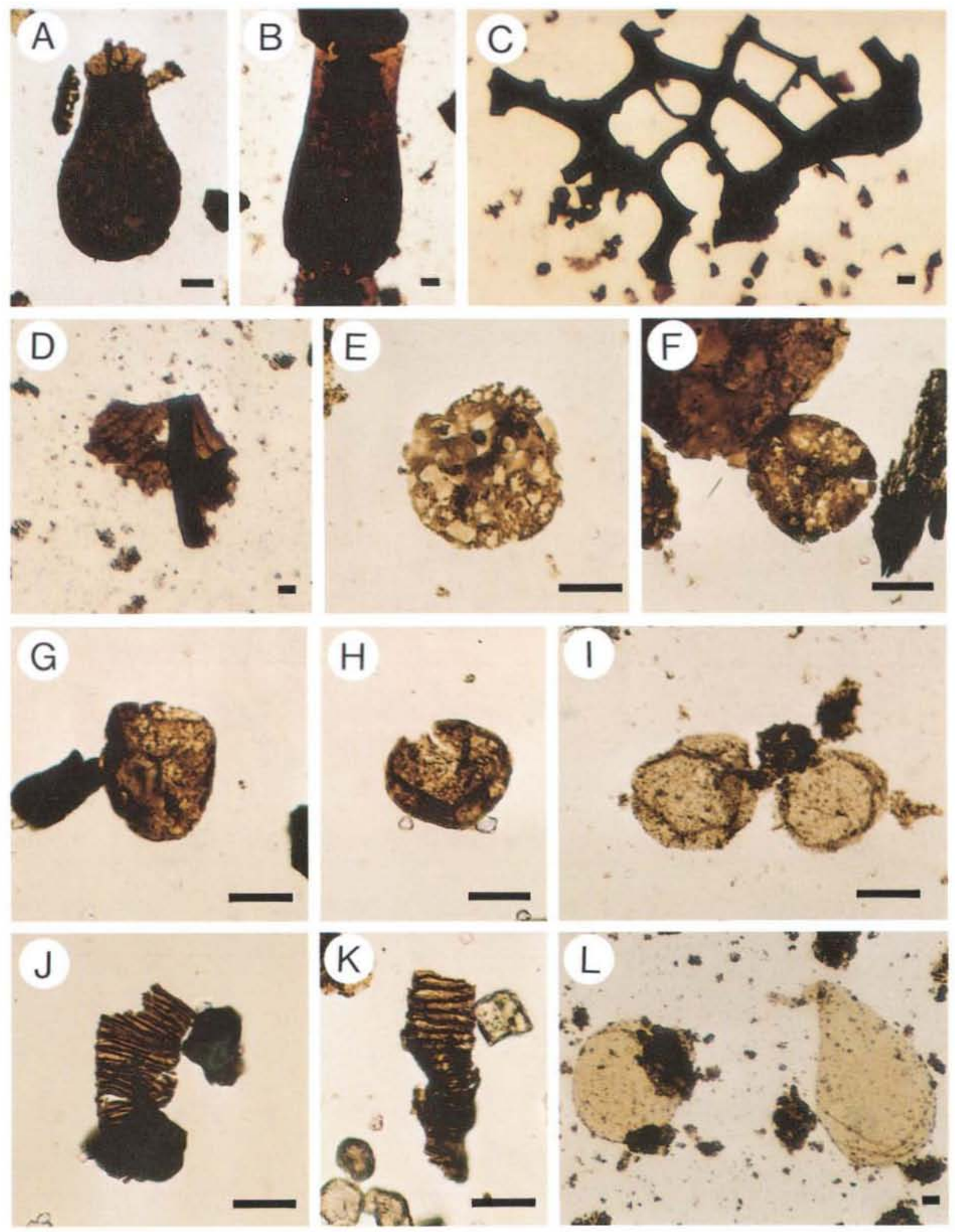


Plate 5. Progressive coloration of amorphous kerogen with increasing thermal alteration
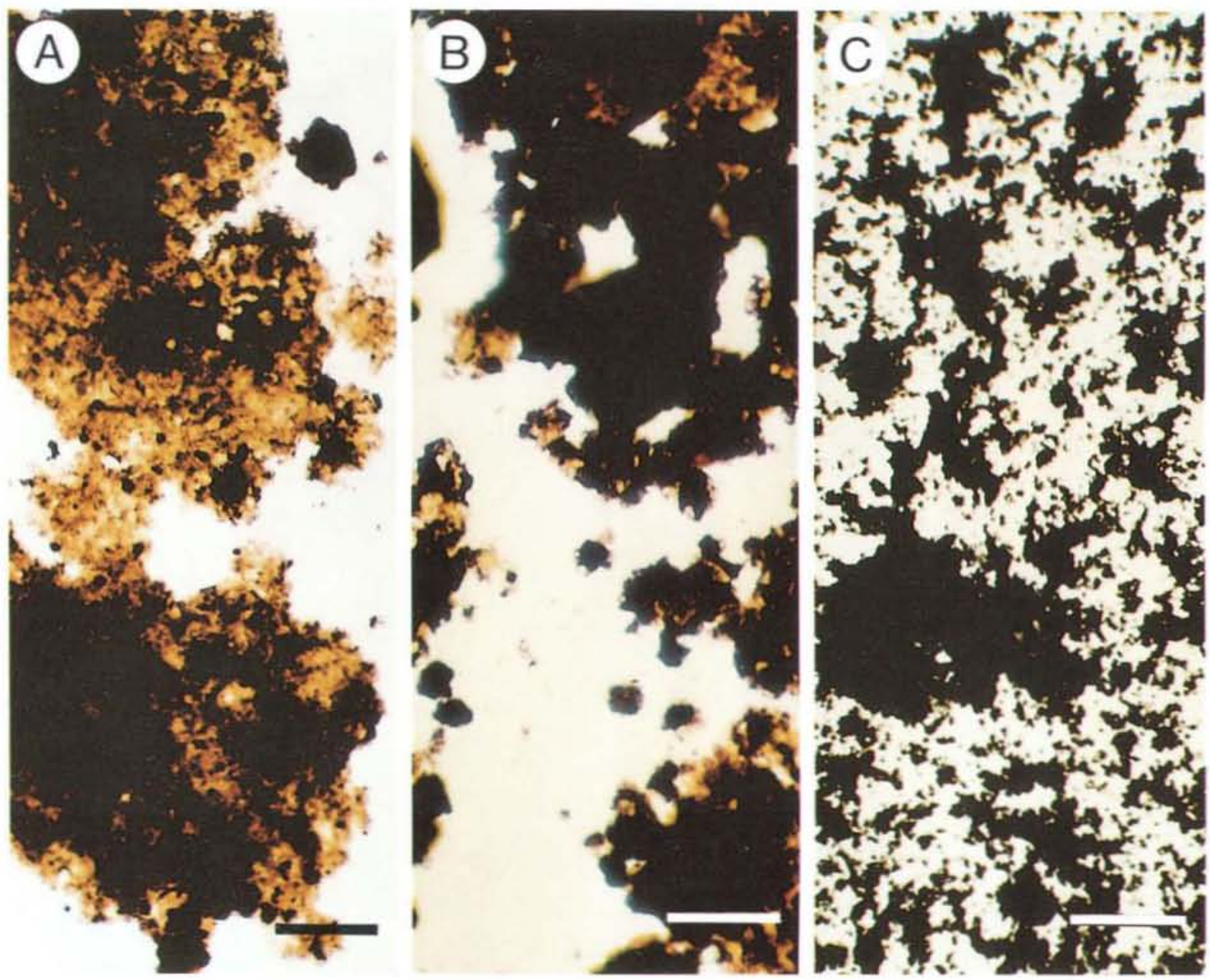

Plate 5. Progressive coloration of amorphous kerogen with increasing thermal alteration Scale bar: $50 \mu \mathrm{m}$
A. TAI: (2)-2+, GGU $211759-2$.
B. TAI: $2^{+}-\left(3^{-}\right)$, GGU $324405-2$.
C. TAI: $4^{+}$, GGU $316475-1$. 
Plate 6. Change in structure of amorphous kerogen with increasing thermal alteration as observed in the scanning electron microscope
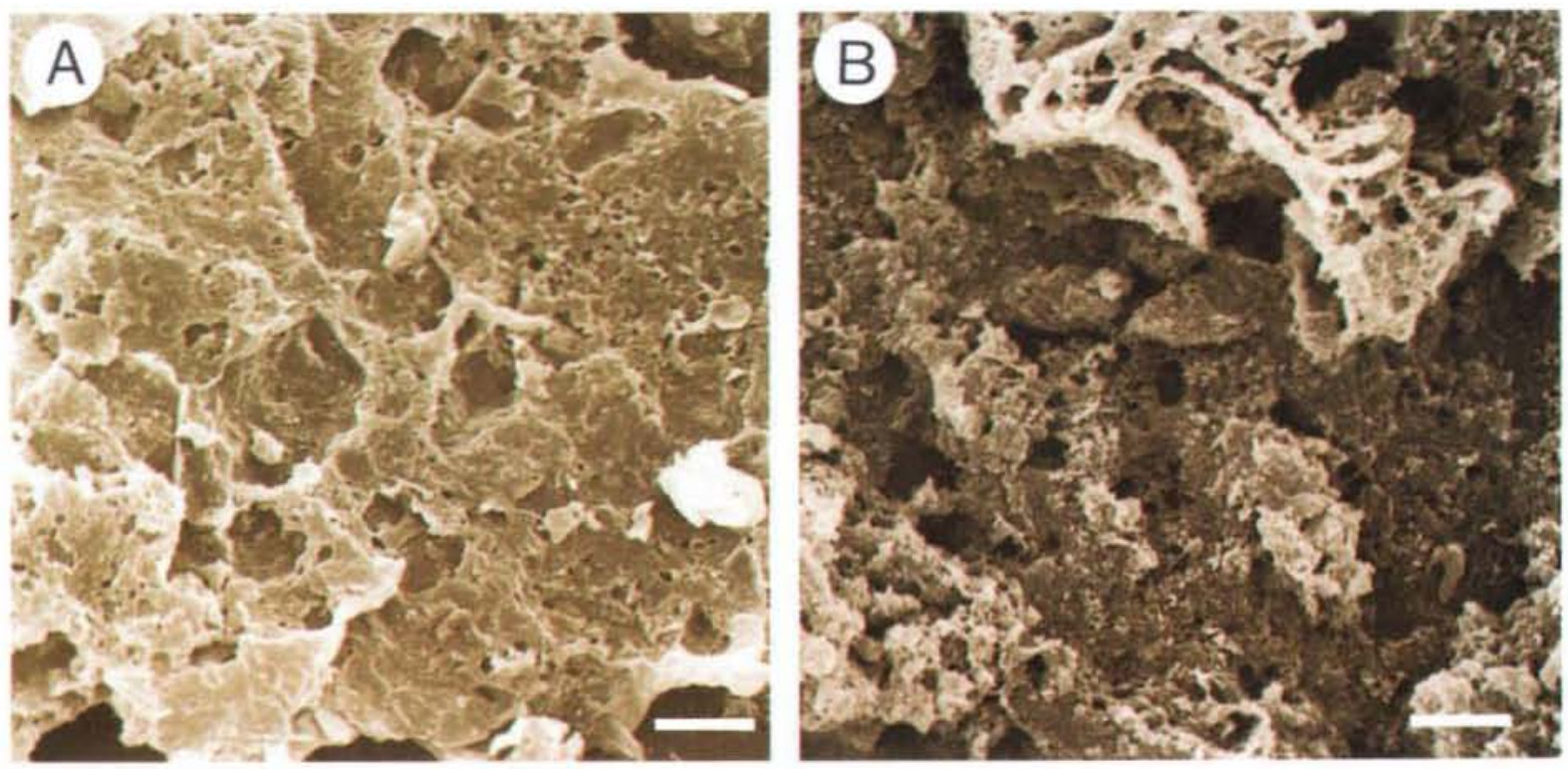

Plate 6. Change in structure of amorphous kerogen with increasing thermal alteration as observed in the scanning electron microscope

A. TAI: $2^{*}-(3), T_{\max }: 446$, GGU $324405-2$, scale bar: $10 \mu \mathrm{m}$.

Plate 7. Field appearance of bitumen

A. Seeping asphalt from southern Wulff Land (equivalent to GGU 324200).

Plate 8. Macroscopic bitumen in slabs

A. Asphalt from seep in dolomite breccia. GGU $324200 \mathrm{~A}$.

B. Like A. Stained. D0, D1, D2, C1, C2 correspond to generations of dolomite and calcite.

\section{Plate 9. Bitumen in thin section}

A. Bitumen in coral. GGU 324130B, Lafayette Bugt Formation. Nyeboe Land. Plane light, stained, C: calcite, Fe-C: Fe-rich calcite, B: bitumen, scale bar: $1 \mathrm{~mm}$.

B. Bitumen in coral. GGU 316067, Lafayette Bugt Formation, Washington Land. Crossed nicols + gypsum plate. Q: quartz, C: calcite, B: bitumen, scale bar: $1 \mathrm{~mm}$.

C. Bitumen-filled fracture in calcarenite. GGU 318013-09, Lafayette Bugt Formation. Nyeboe Land. Plane light, scale bar: $2 \mathrm{~mm}$.
B. TAI: $4^{*}, T_{\max }: \mathrm{n} . \mathrm{d}$, GGU $316475-2$, scale bar: $10 \mu \mathrm{m}$.

B. Hard solid bitumen in dolomite vug in the Sydpasset Formation (equivalent to GGU 324287-324299, core GGU 318003).

C. Asphalt from seep in dolomite breccia. Stained. Same generations of carbonates as A and B. GGU $324200 \mathrm{E}$.

D. Hard solid bitumen in vugs and veins in dolomite grainstone. DO: dolomite grainstone, D1: saddle dolomite. Core GGU 318003 .

D. Two-phased bitumen (black and yellow) (B1, B2) in saddle dolomite veins (D1) cross-cutting dolomite grainstone (D0). See close-up (arrow) in Plate 11. GGU 318003-53, Henson Gletscher Formation, Freuchen Land. Plane light, scale bar: $2 \mathrm{~mm}$.

E.-F. Saddle dolomite vein (D1) in dolomite grainstone (D0). Bitumen occurs as impregnation in DO (B1), as residual matter in the contact between D0 and D1 (B2, $R_{0}: 0.92 \%$ ) and in the centre of the vein (B3, $R_{v}: 1.21 \%$ ). GGU 318003-21. Sydpasset Formation, Freuchen Land. Plane light, scale bars: $1 \mathrm{~mm}$.

Plate 10. Bitumen in palynologically prepared samples observed in microscope or in SEM

A. Bitumen with flaky appearance (note crystal impressions). GGU 315172-1. Ryder Gletscher Group Fm 6, Wulff Land. Scale bar: $25 \mathrm{um}$.

B. Globular bitumen. GGU 315865-2, Aftenstjernesø Formation, Nares Land, scale bar: $50 \mu \mathrm{m}$.

C. Globular bitumen which has been extruded during and after sample preparation by the xylene-containing mounting medium. GGU 315199, Ryder Gletscher Group Fm 6. Warming Land. Scale bar: $12.5 \mu \mathrm{m}$.
D. Bitumen with flaky appearance (note crystal impressions). GGU 315172-1. Ryder Gletscher Group Fm 6, Wulff Land. Scale bar: $10 \mu \mathrm{m}$.

E. Bitumen mirroring imprints of crystals from coral space. GGU 316067-2. Lafayette Bugt Formation, Washington Land. Scale bar: $10 \mu \mathrm{m}$.

F. Thread-like bitumen. GGU 324453, Buen Formation, Wulff Land. Scale bar: $25 \mu \mathrm{m}$. 
Plate 7. Field appearance of bitumen

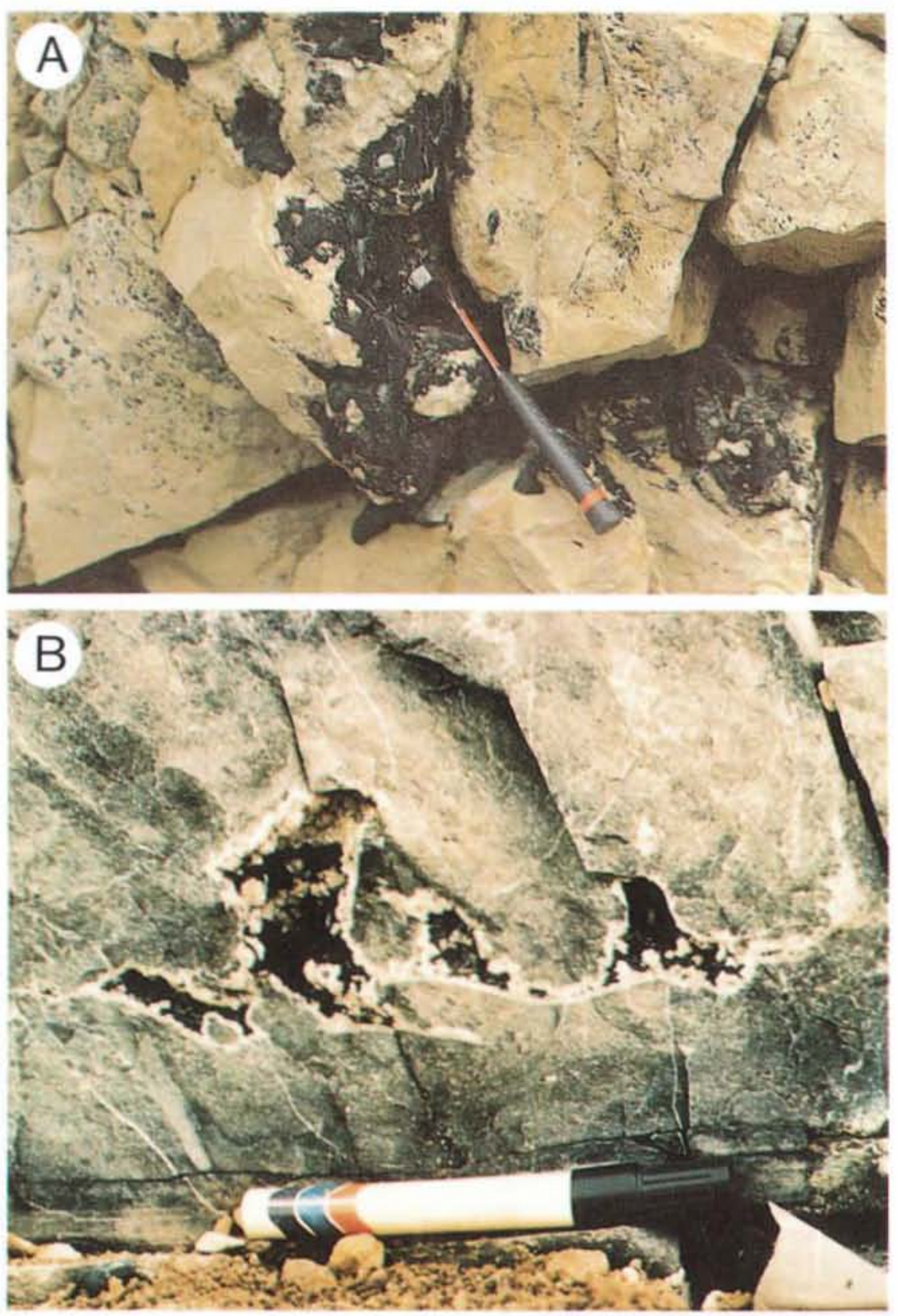


Plate 8. Macroscopic bitumen in slabs
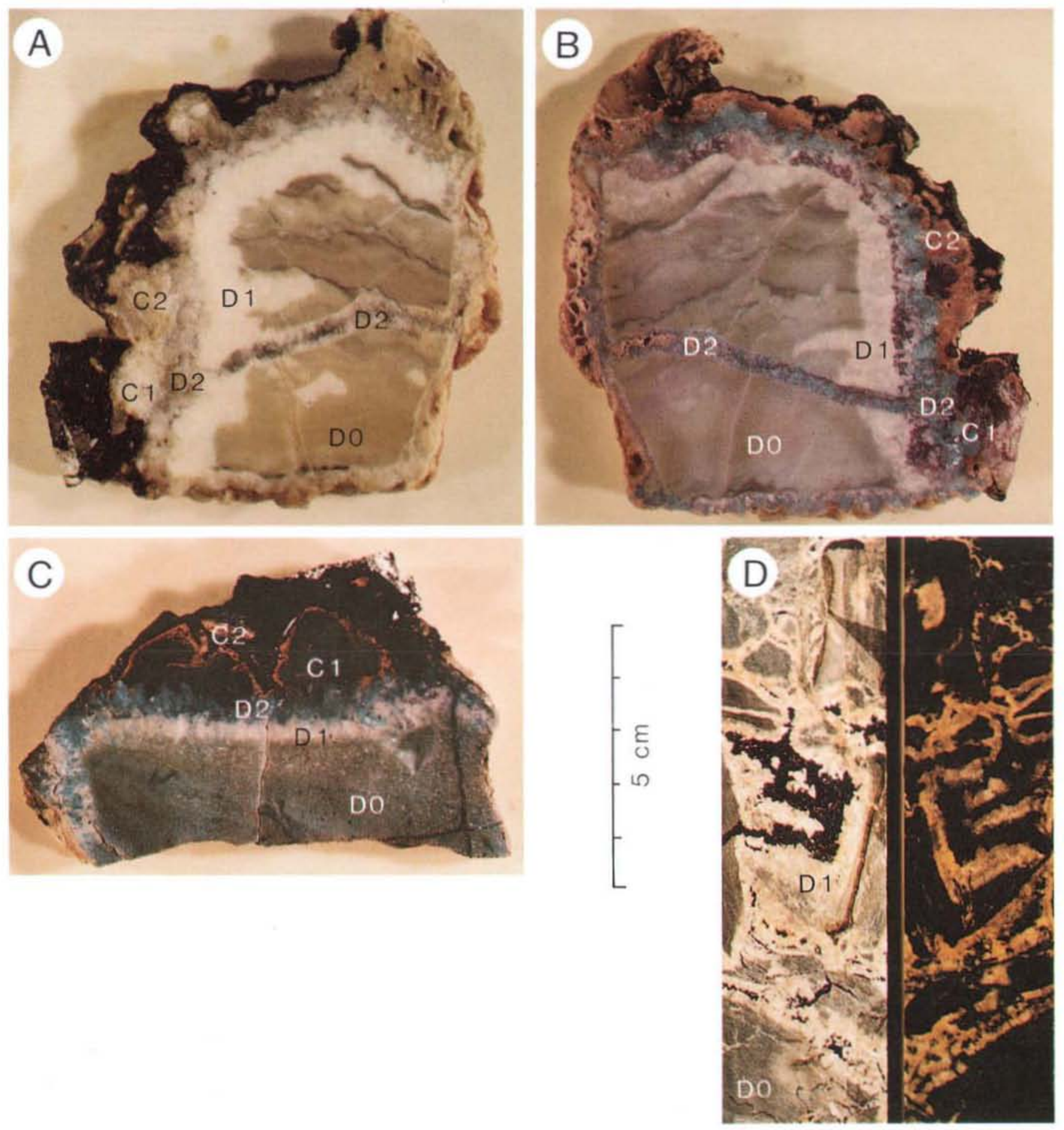
Plate 9. Bitumen in thin section

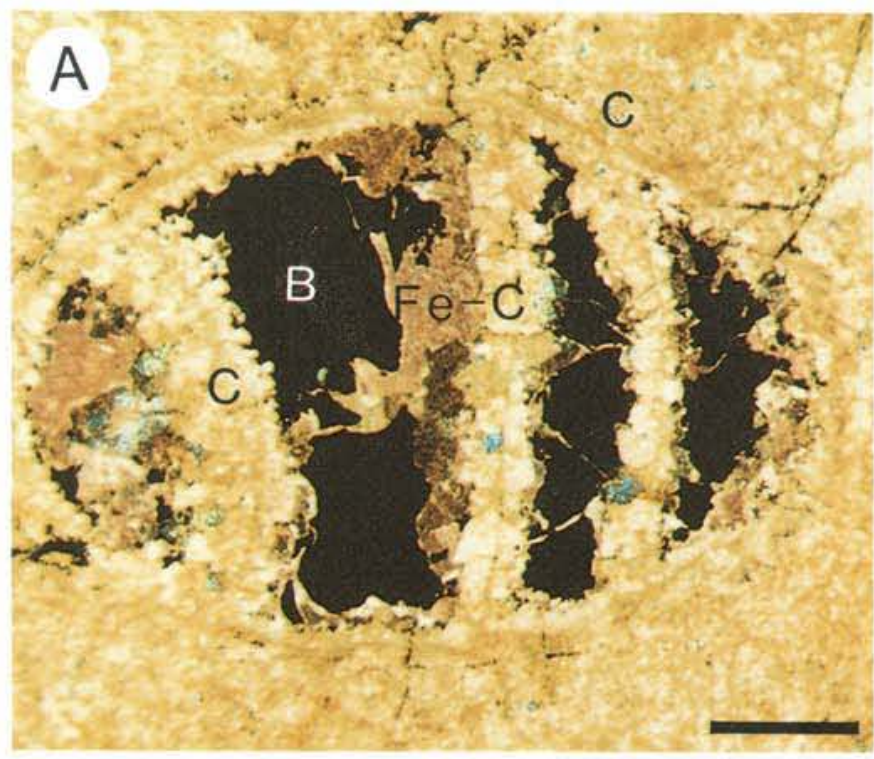

C

F. Af:
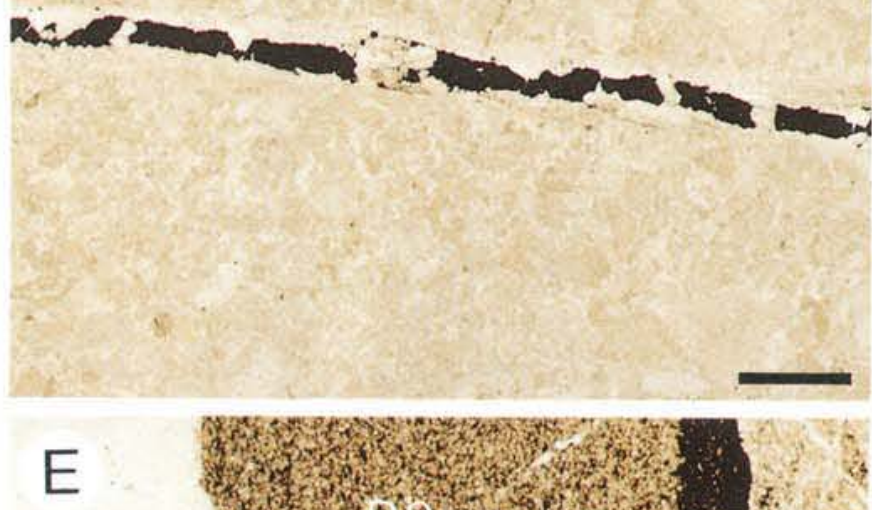

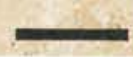

E

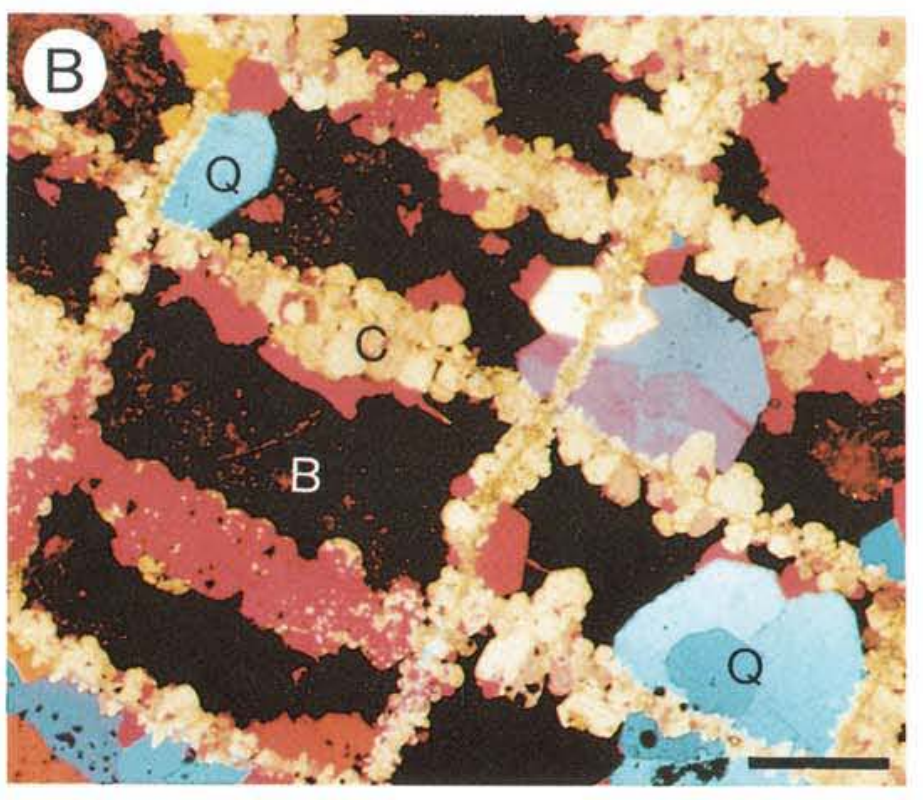

D

Dó

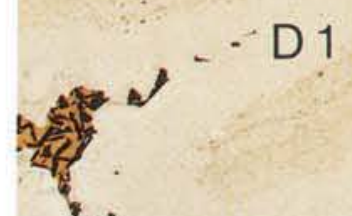

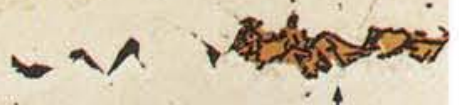 \\ $\mathrm{B} 1,{ }^{4} \mathrm{~B} 2$}

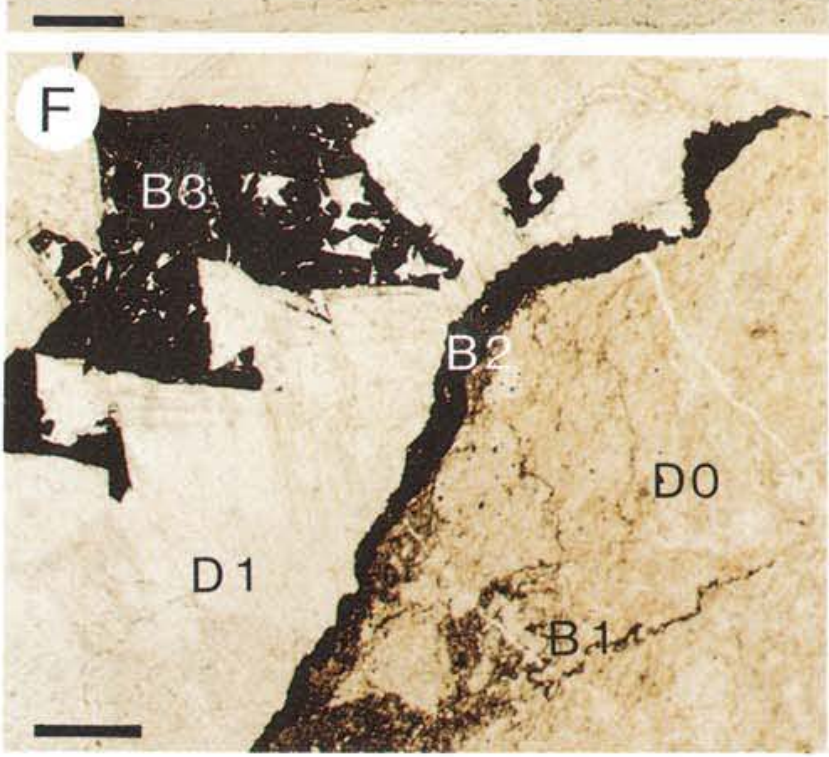


Plate 10. Bitumen in palynologically prepared samples observed in microscope or in SEM
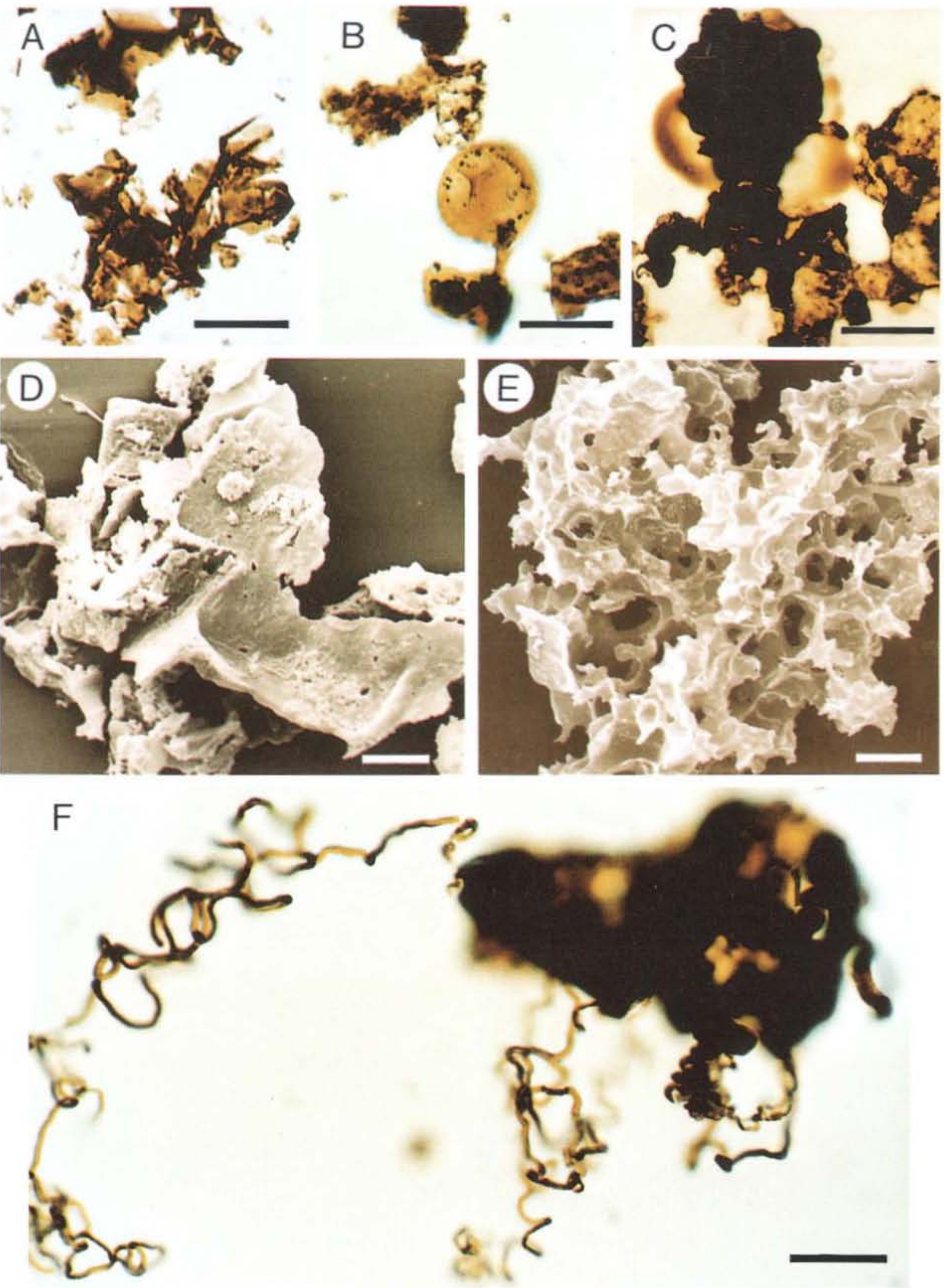
Plate 11. Bitumen in polished section
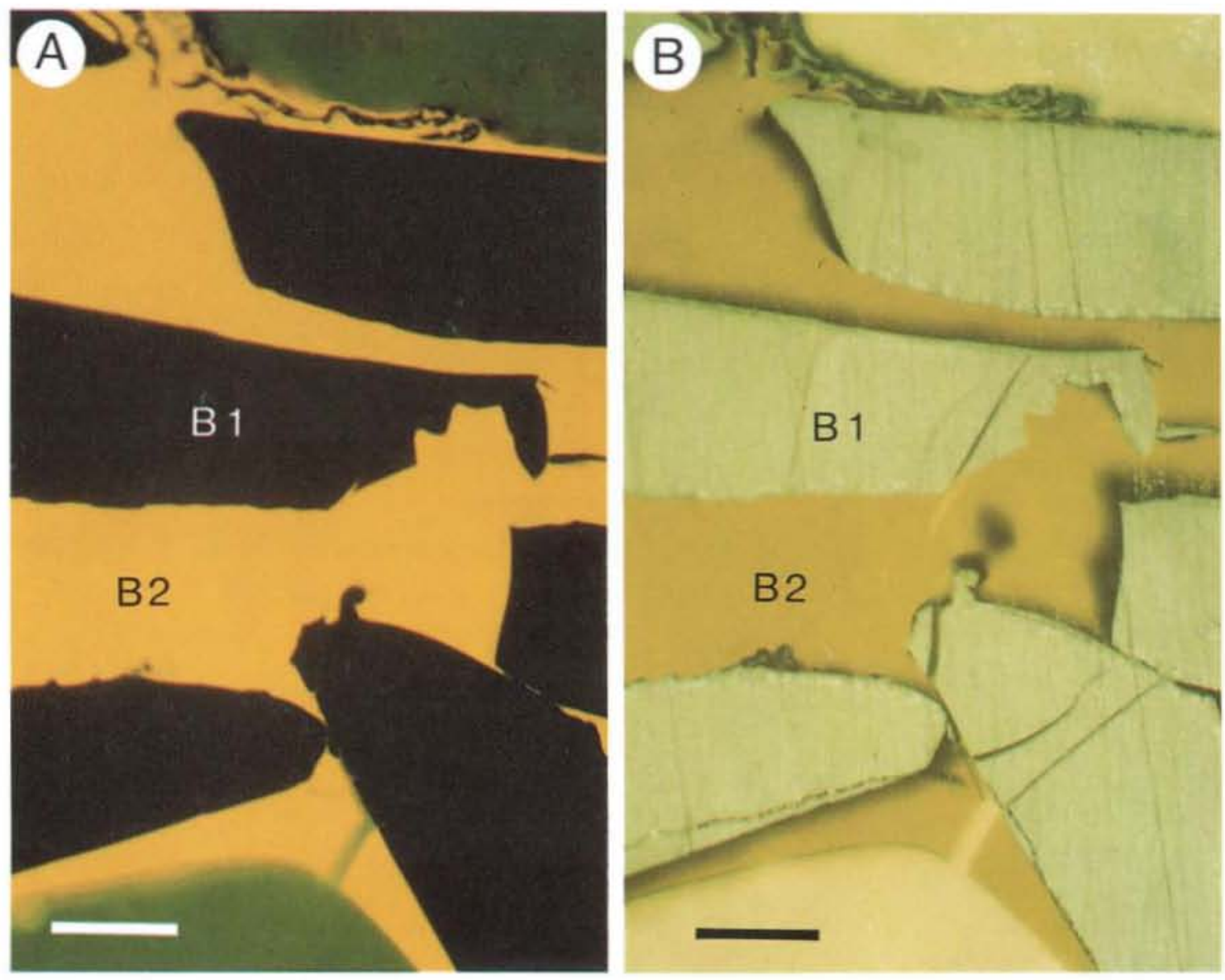

Plate 11. Bitumen in polished section

GGU 318003-53, Henson Gletscher Formation, Freuchen Land.

Scale bar: $50 \mu \mathrm{m}$

A. Fluorescent light photograph of two-phase bitumen.

B. Normal reflected light photograph of same field. The yellow-fluorescent low-reflecting bitumen (B2) has a $\mathbf{R}_{\mathrm{o}}$ of $0.08 \%$ and the dark non-fluorescent high-reflecting bitumen (B1) a $\mathrm{R}_{\mathrm{o}}$ of $1.17 \%$.

\section{Cover picture}

Cambrian and Ordovician strata at Blue Cliffs, Wulff Land, North Greenland. Photo: J. Lautrup, GGU. 